\title{
Sharing the results of a high-resolution ocean general circulation model under a multi-discipline framework-a review of OFES activities
}

\author{
Yukio Masumoto
}

Received: 30 November 2009 / Accepted: 4 May 2010/Published online: 19 May 2010

(C) The Author(s) 2010. This article is published with open access at Springerlink.com

\begin{abstract}
Quasi-global, eddy-resolving ocean general circulation model experiments, so-called OFES (ocean general circulation model for the Earth Simulator) project, have been conducted with a basic concept of sharing results among scientists in a multi-discipline framework. Studies using such OFES results extend widely from the physical aspects of ocean circulations and energy considerations to biogeochemical tracer distributions and marine ecosystem dynamics. This article reviews the OFES activities during a period from 2004 to 2009 and highlights some interesting scientific results that emerged from the OFES project. Future plans of the project are also presented.
\end{abstract}

Keywords Eddy-resolving simulation - Ocean general circulation model $\cdot$ Multi-disciplinary project

\section{Introduction}

It has been known that phenomena in the ocean and associated variability in ocean circulations and tracer fields distribute over wide spectra in terms of both temporal and spatial scales. Interactions among the different space- and time-scales are key elements for a better understanding of

Responsible Editor: Hideharu Sasaki

Y. Masumoto $(\bowtie)$

Research Institute for Global Change,

Japan Agency for Marine-Earth Science and Technology,

Yokohama, Kanagawa, Japan

e-mail: masumoto@jamstec.go.jp

Y. Masumoto

Department of Earth and Planetary Science,

Graduate School of Science, University of Tokyo,

Tokyo, Japan the variability in the real ocean. One example of such interactions is the influences of meso-scale eddies and frontal structures in the ocean on other phenomena with different time- and space-scales and vice versa. In addition, clarification of interactions between physical parameters and biogeochemical activities is an essential issue for improving our knowledge of the ocean as a multi-disciplinary system. A high-resolution ocean general circulation model (OGCM) is a powerful tool to investigate such studies on the scale interactions in the ocean.

With rapid advances in the high-performance computational sciences, several high-resolution global OGCM simulations are conducted at several institutions (e.g., Semtner and Chervin 1992; Coward et al. 2002; Maltrud and McClean 2005). Preliminary results from the Ocean Circulation and Climate Advanced Modelling Project (OCCAM) model simulation with horizontal grid spacing of $1 / 12^{\circ}$ are shown in Coward et al. (2002), and results from a 15-year integration using the global Parallel Ocean Program (POP) with $0.1^{\circ}$ horizontal grid spacing are reported by Maltrud and McClean (2005). Both results demonstrate realistic eddy activities as well as the largescale circulations, including the global circulation patterns and basin-scale phenomena in the tropical to polar regions. These eddy-permitting or eddy-resolving models provide us with new insights not only into the ocean variability associated with the eddy-scale phenomena themselves but also into influences of these eddies on the large-scale circulations (e.g., Smith et al. 2000; Hurlburt and Hogan 2000; Chassignet and Garraffo 2001).

Despite such advantages of high-resolution ocean modeling, only a limited number of scientists can conduct such computationally intensive tasks with the eddy-resolving OGCM, mainly because the availability of high-performance super computers in the community is rather limited. Even for those who can run the models on an appropriate facility, 
limited resources in CPU time, memory spaces, and disk spaces make it impossible for them to conduct many eddyresolving long-term integrations of the global domain with different model settings.

An ocean simulation group at Japan Agency for MarineEarth Science and Technology (JAMSTEC) has started several years ago a new project to conduct a relatively long-term hindcast integration of the world ocean circulations, using an OGCM specifically modified for use on the Earth Simulator, which is a gigantic super-computer dedicated mainly for the earth science community in Japan. The project is called the OGCM for the Earth Simulator (OFES) project. Considering the above limitations and issues in the high-resolution modeling efforts, a main idea for the OFES project is to share the invaluable outputs among scientists, not only within the physical research community but also to geochemical and ecosystem research communities, and to stimulate the cooperative analyses of the simulated results on the ocean circulations, tracer distributions, marine ecosystems, and their variability. The project started with a main focus on the tropical and subtropical ocean variability at first, but the results have been widely used at present for a variety of purposes.

This article reviews scientific activities using the OFES results during the recent years. In particular, we try to highlight interesting scientific results that emerged by sharing results from high-resolution simulations among scientists in an interdisciplinary framework. By doing so, this article serves as a reference to how the OFES project stimulates many scientists in different fields to collaborate with each other and helps to advance our knowledge of oceanography. It also provides guidance for scientists who would like to use the OFES results and to conduct similar projects. The structure of this paper is rather a collection of highlights in the related papers. We start with a brief model description in "Section 2", and configurations of model integrations and output datasets are described in "Section 3". "Sections 4 and 5" show results from particular examples of eddy-resolving simulations, focusing on the physical analyses and biogeochemical/ecosystem analyses, respectively, to demonstrate achievements of sharing outputs from such a high-resolution simulation. Future directions of OFES project are discussed in "Section 6".

\section{Model description}

OFES is based on the Modular Ocean Model version 3 (MOM3) (Pacanowski and Griffies 2000), developed at Geophysical Fluid Dynamics Laboratory/National Oceanic and Atmospheric Administration (GFDL/NOAA). It is highly tuned for the Earth Simulator, particularly in parallelization and vectorization procedures to attain the best computational performance on the Earth Simulator.

The model solves three-dimensional primitive equations in spherical coordinates under the Boussinesq and hydrostatic approximations, with $z$-level coordinate in vertical. The model domain covers a quasi-global region from $75^{\circ} \mathrm{S}$ to $75^{\circ} \mathrm{N}$ excluding the Arctic Ocean. The horizontal grid spacing and the number of vertical levels are $0.1^{\circ}$ and 54 , respectively. The vertical grid spacing varies from $5 \mathrm{~m}$ at the surface to $330 \mathrm{~m}$ at the maximum depth of $6,065 \mathrm{~m}$. To represent upper ocean circulation realistically, 20 levels are confined in a layer between the sea surface and the $200-\mathrm{m}$ depth. The model topography is generated using $1 / 30^{\circ}$ bathymetry dataset provided from the OCCAM project at the Southampton Oceanography Centre, and we obtain it through GFDL/NOAA (Fig. 1). The partial cell method (Pacanowski and Gnanadesikan 1998) implemented in MOM3, which
Fig. 1 Model domain and bottom topography distribution

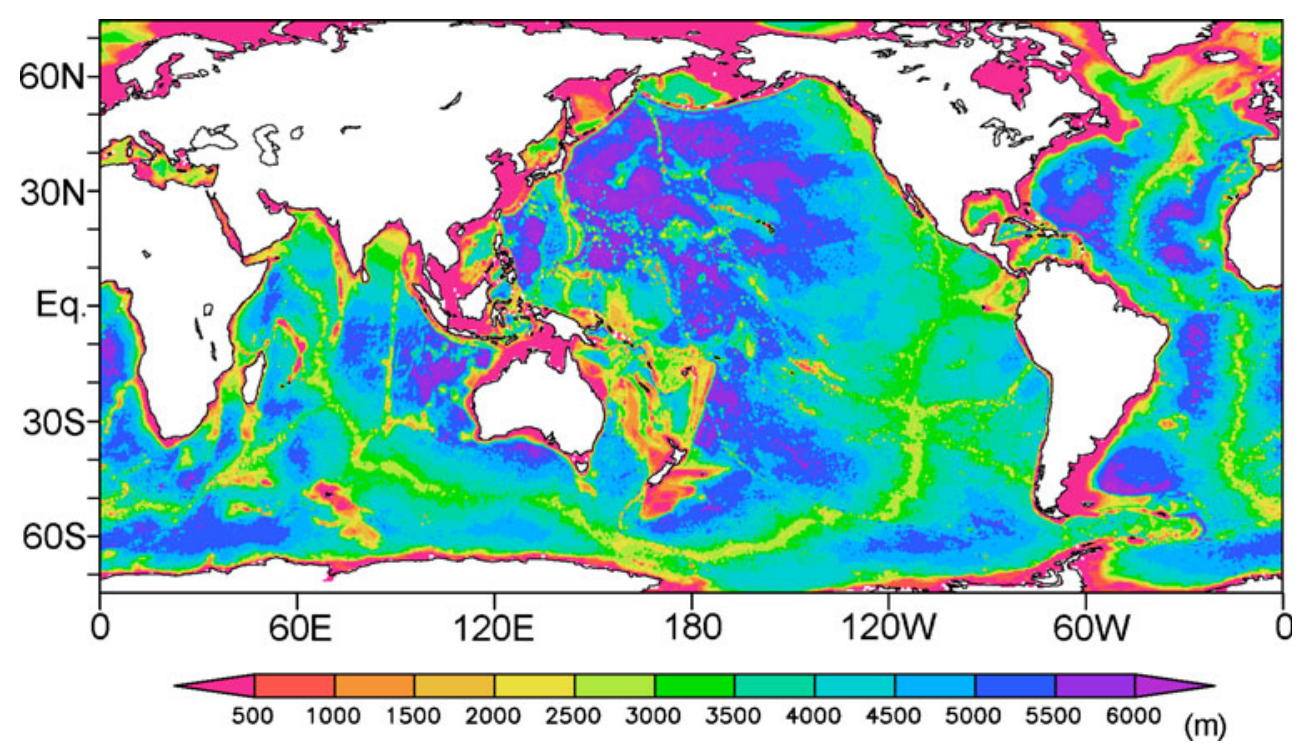


allows bottom ocean cells to be of different thickness, is employed to represent the topography realistically. The model also takes into account the free surface to simulate explicitly the surface height variations so that direct comparison with the satellite altimetry observations can be made.

OFES adopts a simple centered finite difference scheme for calculation of the momentum and tracer advection terms. A scale-selective damping of biharmonic operator is utilized for horizontal mixing of momentum and tracers to suppress computational noises with the horizontal scale of the grid spacing. The viscosity and diffusivity coefficients are calculated as in Smith et al. (2000) with the value of $-2.7 \times 10^{10} \mathrm{~m}^{4} / \mathrm{s}$ for momentum and $-9 \times 10^{9} \mathrm{~m}^{4} / \mathrm{s}$ for tracers, respectively, at the equator. They vary proportional to the cube of the zonal grid spacing and of cosine function of latitude. Vertical viscosity and diffusivity are calculated using the K-profile parameterization (Large et al. 1994).

For surface momentum fluxes, we utilize the NCEP/ NCAR reanalysis products (Kalnay et al. 1996) or QuikSCAT (QSCAT) satellite scatterometer products processed under J-OFURO project (Kubota et al. 2002). The bulk formula of Rosati and Miyakoda (1988) is adopted for the surface heat flux calculation, with the necessary atmospheric variables taken from the NCEP/NCAR reanalysis products. The salinity flux is obtained from precipitation rate of the reanalysis data and evaporation rate is derived using the bulk formula. Additionally, the surface salinity is restored to the climatological monthly mean value of the World Ocean Atlas 1998 (WOA98; Boyer et al. $1998 \mathrm{a}, \mathrm{b}, \mathrm{c})$, with the restoring time-scale of 6 days (equivalent to the piston velocity of $0.83 \mathrm{~m} /$ day), so that the effects of the river run-off are included implicitly. Details of the forcing strategy of OFES runs are described in the following section. In the regions within $3^{\circ}$ latitudinal distances from the northern and southern artificial boundaries at $75^{\circ} \mathrm{N} / \mathrm{S}$, temperature and salinity are restored to the monthly mean climatological values of the WOA98 (Antonov et al. 1998a, b, c; Boyer et al. 1998a, b, c) at all levels, with the restoring time-scale that increases linearly from 1 day at the boundaries to 720 days at $3^{\circ}$ inside from the boundaries. These buffer layers suppress the unrealistic wave propagation along the artificial boundaries and can incorporate the effects of sea ice processes. To avoid from being frozen, the surface heat flux is set to be zero in OFES when the flux is upward and the SST becomes a value lower than $-1.8^{\circ} \mathrm{C}$, a typical freezing temperature of seawater.

For a case of tracer experiment, we incorporate an equation governing the concentration of chlorofluorocarbons (CFCs), in particular CFC-11 and CFC-12, in OFES (Sasai et al. 2004, 2005), and air-sea fluxes of the CFCs in the same way with OCMIP-2 protocol (Dutay et al. 2002) are adopted as a forcing of the tracers. The air-sea CFC flux, $F_{\mathrm{CFC}}$, is calculated using the following equation

$F_{\mathrm{CFC}}=K_{\mathrm{W}}\left(\alpha C_{\mathrm{atm}}-C_{\mathrm{sea}}\right)$

where $K_{\mathrm{W}}$ is the gas transfer velocity, $\alpha$ the solubility of $\mathrm{CFC}$ in seawater, $C_{\text {atm }}$ the partial pressure of CFC in dry air, and $C_{\text {sea }}$ the simulated $\mathrm{CFC}$ concentration at the sea surface. $C_{\mathrm{atm}}$ is assumed to be uniform in each hemisphere, with temporal variations from the reconstructed annual mean mole fraction of $\mathrm{CFC}$ at $41^{\circ} \mathrm{S}$ and $45^{\circ} \mathrm{N}$ (Walker et al. 2000). We assume a linear transition between the two hemispheres between $10^{\circ} \mathrm{S}$ and $10^{\circ} \mathrm{N}$.

A simple marine pelagic ecosystem model that consists of four compartments of the main players in the system, i.e., nutrient, phytoplankton, zooplankton, and detritus (NPZD) (Oschlies 2001; Sasai et al. 2006), is also embedded in OFES (Sasai et al. 2007b). Evolution of biological tracers is governed by the advective-diffusive equation with the sources and sinks due to the biological processes (Sasai et al. 2006). The phytoplankton growth rate depends on the light and nitrate concentration. The light is calculated using the NCEP/NCAR daily mean shortwave radiation data. The biological fields and processes have no feedback to the physical components in the model.

\section{OFES runs and outputs}

OFES integrations consist of several components with different model types (i.e., physical only, including tracers, physical-biological model) and different forcing (Fig. 2). A whole series of integrations starts from 50-year climatological run (Climatology Run), which can be considered as a spin-up integration for the following hindcast runs. The monthly mean climatological values, obtained by taking a mean during 1950 and 1998 from the NCEP/NCAR reanalysis products (Kalnay et al. 1996), are utilized for the wind stresses and the atmospheric variables that need to be specified for the heat and freshwater flux calculations. The initial condition is no motion for the velocity fields and the annual mean temperature and salinity fields obtained from WOA98.

After the spin-up of 50 years, the model ocean is driven by daily mean wind stresses obtained from the NCEP/ NCAR reanalysis for a period from 1950 to 2008 (NCEP Run). The atmospheric variables used for the calculation of the surface heat and freshwater fluxes are taken from the daily mean values of the NCEP/NCAR reanalysis products. As the initial conditions for this hindcast integration, we adopt the last conditions of the 50-year climatological spinup integration. The equation for the CFC-11 concentration is incorporated in this hindcast run. 


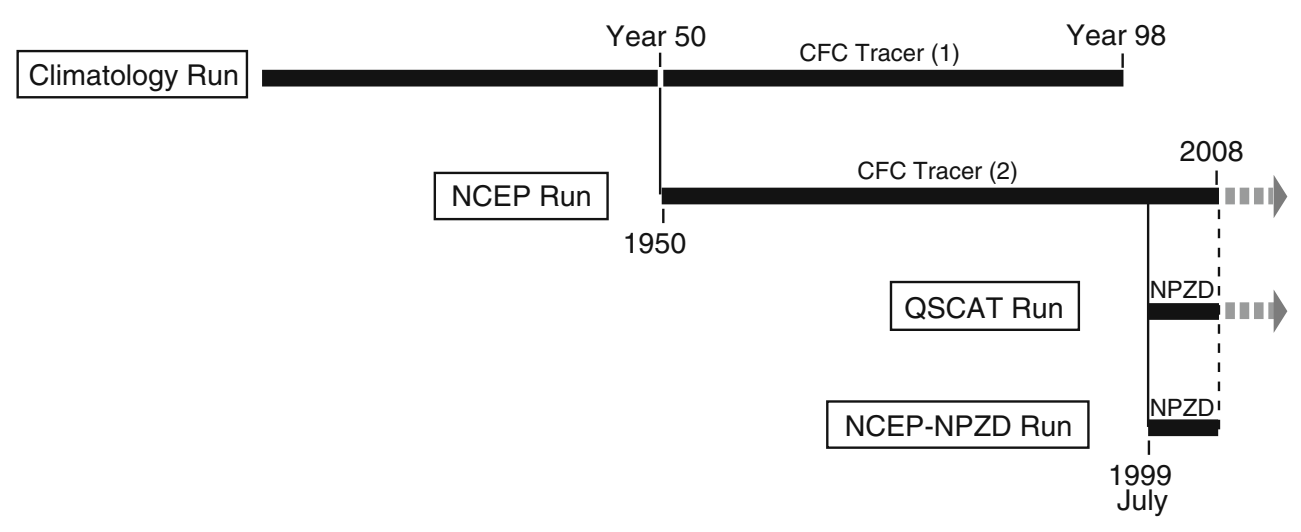

Fig. 2 Schematic diagram showing OFES model integrations. "Climatology Run" is forced by the climatologies of NCEP/NCAR reanalysis, and "CFC Tracer (1)" is forced by the same climatological forcing for the physical part with CFC-11 and CFC-12 boundary condition for 1950 to 1997 . "NCEP Run" is forced by the daily mean forcing from 1950 to 2008 , with CFC-11 calculation embedded ("CFC Tracer (2)"), starting from the conditions at the end of year 50 of

At the same time, the climatological integration is extended further to year-98, with the equations for the CFC-11 and CFC-12 embedded in the model. For this climatological run, the physical part is the same as the spinup integration with the climatological forcing. However, the surface boundary conditions for the CFC tracers vary in time, applying the conditions from 1950 to 1997 during the 48-year integration. The results show the CFC tracer distribution in the climatological circulations under timevarying flux forcing.

Another hindcast integration, named as QSCAT Run, is performed with the wind stresses from the QuikSCAT satellite observation from July 1999 (Sasaki et al. 2006). The QSCAT data is obtained from Japanese Ocean Flux datasets with Use of Remote sensing Observations (J-OFURO) product, which is a daily mean value with $1.0^{\circ}$ grid spacing (Kutsuwada 1998; Kubota et al. 2002). For this integration, the atmospheric variables for the surface heat and freshwater flux estimations are taken from the NCEP/NCAR reanalysis as in the case for the NCEP Run, except for the use of the QuikSCAT wind speed data for the calculation of the latent heat flux. The ocean conditions at the end of June 1999 are utilized as the initial conditions for this integration. The simple NPZD ecosystem model is also embedded in QSCAT Run. The initial conditions for the biological components are taken from the last condition of a 5-year test experiment, in which OFES with the ecosystem model is forced by the climatological forcing. This ensures reasonably realistic initial conditions for the biological parameters.

In order to compare the responses of the biological fields to different wind forcing, NCEP Hindcast Run with the ecosystem model is conducted from July 1999, which is called the NCEP-NPZD Run.
"Climatology Run". "QSCAT Run" is forced by the QuikSCAT satellite winds from July 1999 of "NCEP Run" to 2008, and this includes a simple NPZD-type ecosystem model. "NCEP-NPZD Run" is the same as "QSCAT Run" except for the NCEP/NCAR reanalysis winds for the forcing. "NCEP Run" with CFC-11 and "QSCAT Run" with NPZD ecosystem model will be continued for 2009 and beyond in the future

For all the three hindcast integrations, both 3-dayinterval snapshot data and monthly mean values of the whole model domain are saved. However, due to a quite large amount of the data from these hindcast runs and the limited storage regions in our computer systems, data from the NCEP Run from 1950 to 1979 are sub-sampled into $0.2^{\circ}$ resolution in horizontal directions. For the Climatology Run, the monthly mean values are stored during periods from year-41 to year-50 and from year-51 to year-98. In addition to the monthly mean data, the 3-day-interval snapshot data for 1 year in Year-46 and the daily mean values for all prognostic variables for 8 years from Year-91 to Year-98 are also saved for detailed analyses of short-term variability in the ocean.

\section{Analyses of physical aspects using OFES results}

General performances of OFES in representing the climatological seasonal variations and the intraseasonal-to-decadal variability are summarized in detail in Masumoto et al. (2004) and Sasaki et al. (2008a), respectively (see also Ohfuchi et al. 2005, 2007; Sasaki et al. 2006; Sasaki et al. 2007). Results demonstrate a good agreement with the observed variability in various temporal and spatial scales in the upper oceans, including the seasonal monsoonal circulations in the tropical regions, the El Niño/La Niña phenomena, the Indian Ocean Dipole events, the Atlantic Meridional modes, and the Pacific and Pan-Atlantic decadal variability. The intraseasonal variability associated with instabilities in the ocean as well as atmospheric short-term variations is also well captured in OFES. In this section, we briefly review the scientific outcomes from detailed analyses of the OFES results in terms of the physical component of the ocean variations. 


\subsection{Global perspectives}

Energy input from the atmosphere and its redistribution within the ocean determine how the ocean circulates and changes. Von Storch et al. (2007) tackle this issue by analyzing kinetic energy budget in the upper ocean in OFES. The power generated by surface winds is estimated to be about $3.8 \mathrm{TW}$, of which about $30 \%(1.1 \mathrm{TW})$ is available to the deeper ocean beneath $110-\mathrm{m}$ depth. They also demonstrate that the main pathway of the windgenerated power downward is due to shear-induced stress and pressure term.

Interaction between the meso-scale eddies and sloping bathymetry for generation of mean flow and its influences on the large-scale ocean circulation is investigated by Merryfield and Scott (2007). In the eddy-resolving model, such as OFES, the mean currents over sloping bathymetry tend to align with the direction of topographic Rossby wave propagation, which is consistent with theories of eddytopographic interaction. Coarser non-eddy-resolving models exhibit oppositely aligned flows, suggesting an essential role of the meso-scale eddies in determining the direction of mean circulation over slopes.

Baroclinic Rossby waves, among others, are essential constituents responsible for ocean variability in the regional and global domains. It has been known that the observed phase speed of the baroclinic Rossby waves differs from that estimated by a linear theory (Chelton and Schlax 1996), and interaction with the background baroclinic zonal flow (Killworth et al. 1997) and an effect of bottom pressure decoupling (Tailleux and McWilliams 2001) have been proposed as possible mechanisms for the differences. Aoki et al. (2009) investigated in detail how these two mechanisms affect the phase speed of the mid-latitude Rossby waves by the use of the OFES outputs. They showed that the simulated Rossby wave speed is well explained by a theory including finite wavelength effects as well as the influences from the background flow and bottom pressure decoupling (Fig. 3). It turns out that the dominant factor among these three effects is the bottom pressure decoupling, which is well reproduced in OFES owing to the high horizontal grid spacing with the partial cell scheme.

\subsection{Variability in the Pacific Basin}

The OFES results are extensively utilized for analyses on several phenomena that appear in the Pacific Ocean. Multiple zonal jet-like structures with typical meridional scale of $300 \mathrm{~km}$ in the mid-latitude regions are highlighted in Maximenko et al. (2005) for the global domain and in Richards et al. (2006, 2008) and Maximenko et al. (2008) for the Pacific basin, respectively (Fig. 4), using the OFES outputs, together with other observational and simulated results. The OFES results reproduce these vertically coherent jet-like structures realistically in terms of the spatial scales, locations, and their time evolutions. Those papers suggest that the jet-like structures have a strong
Fig. 3 Comparison of Rossby wave phase speed between OFES simulation and theoretical estimations in the Pacific Ocean. a Meridional profile of phase speed of baroclinic Rossby wave simulated in OFES (open circles) and estimated from long wave theories that include the finite wavelength effect. Theoretical phase speed is calculated for a simple standard theory (solid lines, $C_{s+\mathrm{K}}$ ), with influence of background currents (dash-dotted lines, $C_{\mathrm{Ug}+\mathrm{K}}$ ), with bottom pressure decoupling effect $\left(C_{\mathrm{BPD}+\mathrm{K}}\right)$, and with both additional effects $\left(C_{\mathrm{Ug}+\mathrm{BPD}+\mathrm{K}}\right)$. b Ratio of the Rossby wave phase speeds in the simulation to the theoretical values (from Aoki et al. 2009)
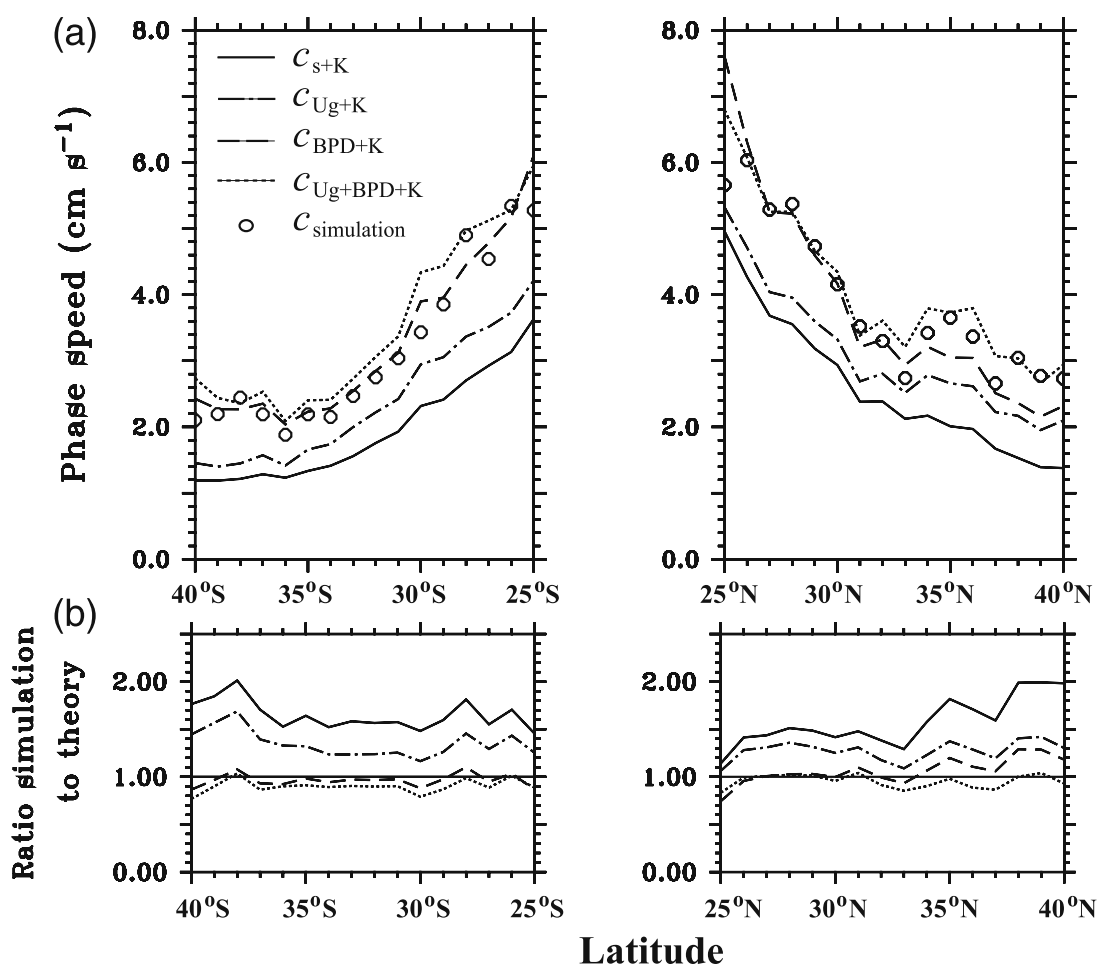
association with the Rossby waves and the meridional scale is consistent with the Rhines scale (Rhines 1975). The realistic topography in the high-resolution models may also play an important role in generating these jet-like structures. Mechanisms responsible for the generation of these curious structures are still open for discussion, and the OFES results may contribute to unveil the problem. Indeed, Melnichenko et al. (2010) investigate the dynamics of the quasi-stationary jet-like structures and suggest that, although the nonlinear processes are important, the linear dynamics cannot be rejected.

Kuroshio-Oyashio confluence and extension region (KOCER), located east of Japan in a latitude band roughly between $30^{\circ} \mathrm{N}$ and $45^{\circ} \mathrm{N}$, is characterized by several eastward jets associated with strong temperature fronts, which form the boundary between the subtropical and subarctic gyre circulations. In addition, active meso-scale eddies and planetary wave penetration from the east significantly modify the conditions in this region at various time-scales. Analysis of the OFES results focusing on this particular region is one of the main activities for the OFES research group. OFES simulates well the observed characteristics in KOCER, such as the similarities and differences between the Kuroshio Extension (KE) front and Oyashio front. For example, the KE front has a deep structure with a strong sea surface height gradient and a modest temperature gradient across the front, while the Oyashio front shows a shallow structure with a tight gradient in temperature field but not for the sea surface height field (Nonaka et al. 2006).

Decadal variability in KOCER is investigated extensively in Nonaka et al. $(2006,2008)$ and Taguchi et al. (2007). Nonaka et al. $(2006,2008)$ show that the decadal-scale cooling tendency from early 1970 s to mid-1980s is associated with southward shifts of the fronts with significant subsurface cooling, and the associated salinity changes appeared in the KE front while the pronounced cooling tends to be confined in the mixed layer in the Oyashio front (Fig. 5). It is also suggested that the variability in the two frontal regions are governed by different processes: propagation of baroclinic Rossby waves from the central North Pacific is a dominant factor controlling the variability in the KE front, while advection associated with intensification of Oyashio, the western boundary current of the subarctic gyre in the North Pacific Ocean, cannot be neglected for the Oyashio front variations. Strong relations between the Oyashio variability and the basin-scale wind stress over the North Pacific subarctic region through the barotropic and baroclinic Rossby waves are also confirmed both for the interannual and decadal time-scales (Nonaka et al. 2008).
Fig. 4 Zonally coherent zonal current structures in the global ocean. a Zonal current anomalies (in $\mathrm{cm} / \mathrm{s}$ ) at the depth of $1,000 \mathrm{~m}$ and $\mathbf{b}$ geostrophic zonal current anomalies at the sea surface derived from OFES results. The zonal current anomalies are deviations from 6-year (45th to 50th model-year) mean of the climatological run, and the geostrophic zonal current anomalies are derived from the simulated sea surface height anomalies, which are deviations from 9-year (42nd to 50th model-year) mean of the climatological run. The currents are averaged over 4 months centered on March of the 48th year of the Climatology Run (from Maximenko et al. 2005)
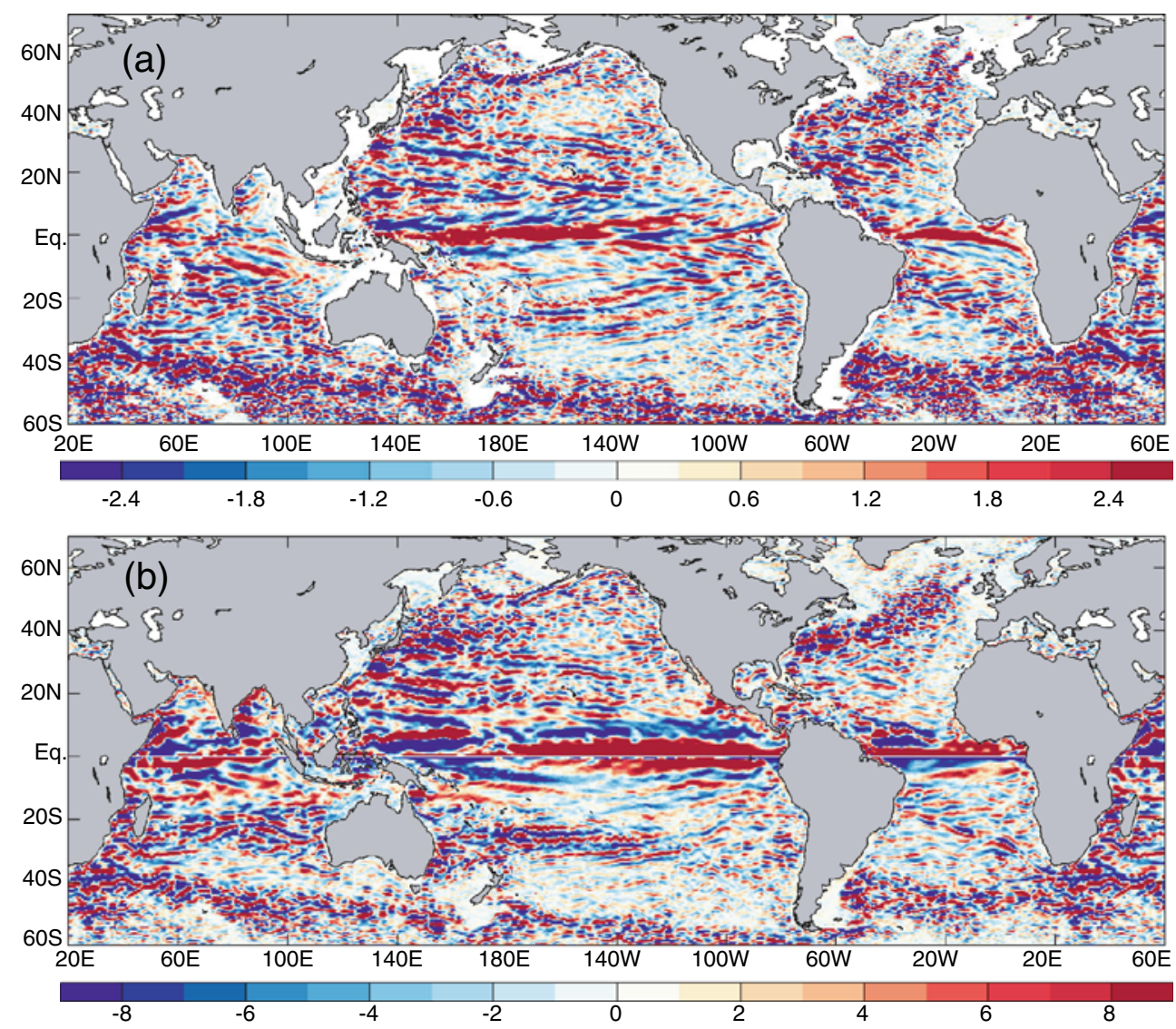
Fig. 5 Frontal structures in the Kuroshio/Oyashio extension region in the northwestern Pacific Ocean simulated in OFES. Latitude-depth sections of winter (January-March) mean temperature (left) and salinity (right), averaged between $145^{\circ} \mathrm{E}$ and $165^{\circ} \mathrm{E}$ for three 5 -year periods for 1968-1972, 1976-1980, and 1984-1988 from NCEP Run. Contour intervals are $1^{\circ} \mathrm{C}$ and $0.1 \mathrm{psu}$ for temperature and salinity, respectively. The corresponding anomalies from their 1950-2003 climatologies are indicated in color shading (From Nonaka et al. 2006)
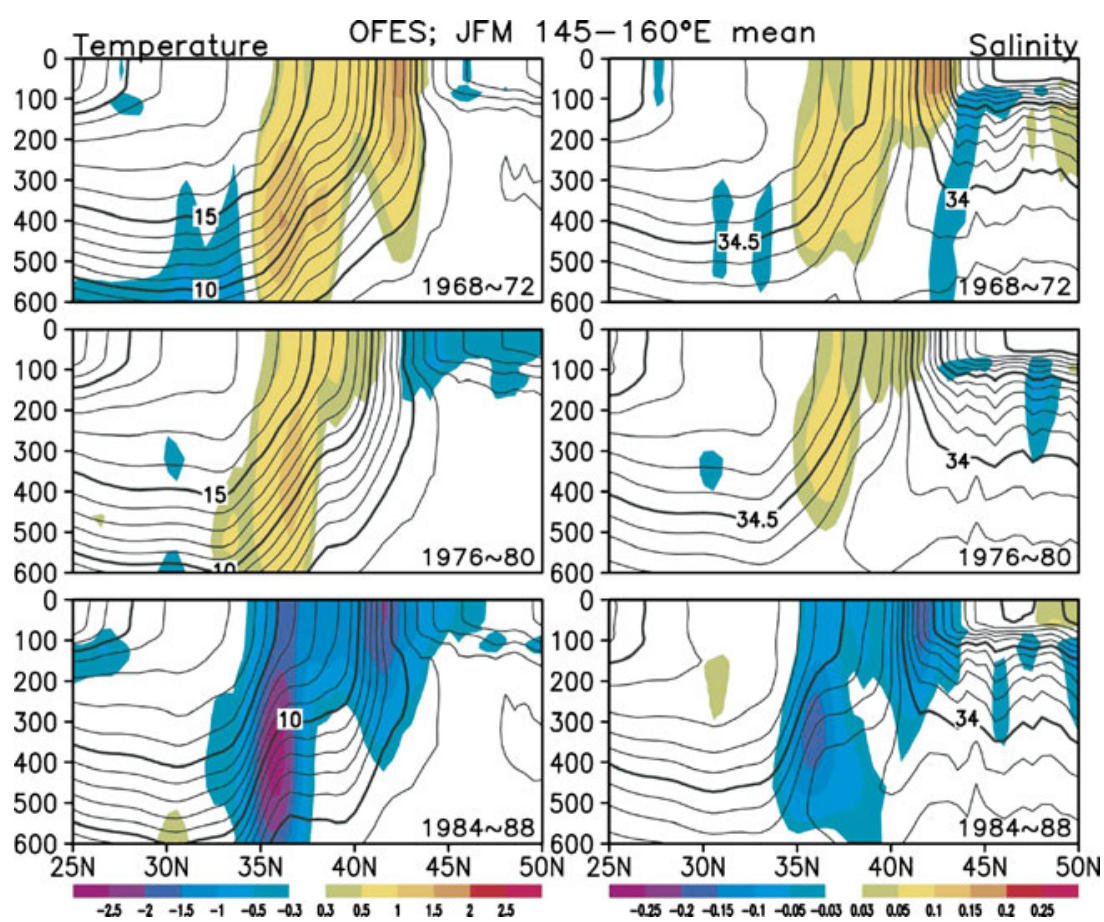

An empirical orthogonal function (EOF) analysis of the sea surface height variability by Taguchi et al. (2007) demonstrates the similar changes with those indicated in Nonaka et al. (2006) as a leading mode during mid-1970s associated with the 1976/1977 shift in the basin-scale wind forcing. The second mode indicates quasi-decadal variations in the KE front region. Together with results from a simple linear Rossby wave model, Taguchi et al. (2007) suggest that the variability consists of a broad-scale variations associated with the basin-scale wind variability and a frontal-scale variations associated with intrinsic mode in KOCER (Fig. 6).

The above interannual-to-decadal variability in KOCER seems to have a strong relation to a basin-scale gyre oscillation, called the North Pacific Gyre Oscillation (Ceballos et al. 2009), which includes variations not only of temperature and salinity but also of nutrient and chlorophyll concentrations. Although the study focuses on the dynamical part of the oscillation, OFES could provide a good opportunity to investigate physical-ecosystem relations in such a long-term variability in the North Pacific Ocean.

Recently, the similar decadal variability is detected in subduction rate in the North Pacific Ocean, which seems to be associated with the Pacific Decadal Oscillation (Qu and Chen 2009). The OFES results suggest that this variability in the subduction rate is due to changes in winter mixedlayer depth, which in turn are closely related to changes in surface wind and heat flux.

Kawai et al. (2008) estimate decadal variations in meridional heat transport across $24^{\circ} \mathrm{N}$ in the North Pacific Ocean using various datasets, including the OFES results.
The decadal-scale changes with an amplitude of approximately $0.1-0.2 \mathrm{PW}$ are detected consistently among different calculations and datasets. Detailed analyses indicate that the increased heat transport during 1980s is mainly due to Ekman transport, while the Kuroshio temperature transport significantly contributes to the increase in the 1990s.

Formation and maintenance of recirculation gyres associated with the western boundary currents, particularly in KOCER, are not well understood and have long been open questions. Qiu et al. (2008) focus on a mid-depth, time-mean recirculation gyre located to the north of the KE, using both the observation data and the OFES hindcast results. The OFES results contribute to clarify the timemean momentum balance in the recirculation gyre and show that horizontal convergence of Reynolds stresses strengthen the KE jet and generate westward mean flow to the north of the jet (Fig. 7).

Further upstream in the East China Sea, the Kuroshio flows northward along the continental slope in the Okinawa Trough, which is a relatively deep basin located between the continental shelf and the Nansei island chain that divides the East China Sea from the Pacific Ocean. Due to limited observation data and complicated topography in this region, much of the structures and dynamics of the Kuroshio in the Okinawa Trough remain unclear. Nakamura et al. (2008) investigate the deep countercurrent beneath the Kuroshio in this area, using the moored current meter data and the OFES results. The simulated results suggest that the persistent countercurrent, which is similar to the observed one, appears in the southern part of the Okinawa Trough throughout the year, while the countercurrent in the 
Fig. 6 Decadal variations as seen in different spatial scales and associated processes in the North Pacific Ocean. Mean sea surface height distribution for a 1968-1980 and b 1984-1996, before and after the major climate shift in the North Pacific Ocean, respectively. Contour intervals are $10 \mathrm{~cm}$. c Broadscale component and $\mathbf{e}$ meso-scale component of the SSH difference between the two 13-year periods shown in a and b (i.e., [1984-1990]-[19681980]). Solutions from a simple in $\mathbf{d}$ to explain the broad-scale component of the differences. Black contours in $\mathbf{c}$ and $\mathbf{d}$ are the SSH distribution averaged between $\mathbf{a}$ and $\mathbf{b}$ (contour interval of $10 \mathrm{~cm}$ ), while those in $\mathbf{e}$ are the differences of the two periods (contour interval of $5 \mathrm{~cm}$ ) (from Taguchi et al. 2007) Rossby wave model are shown (a) OFES unfiltered (1968-80)

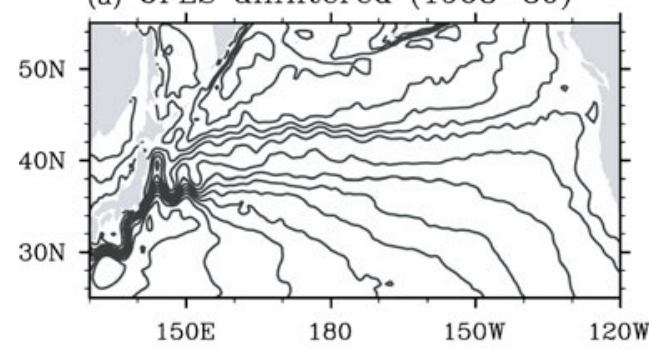

(c)

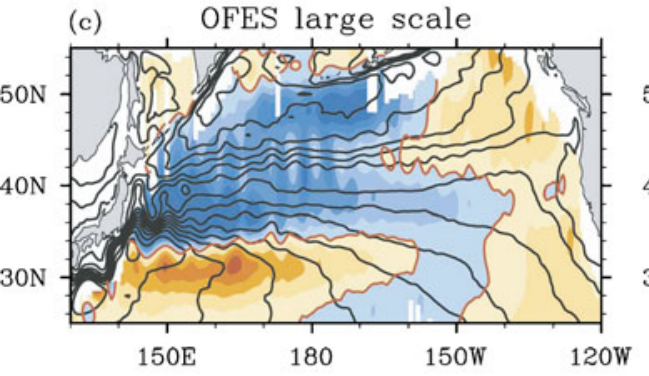

(b) OFES unfiltered (1984-96)

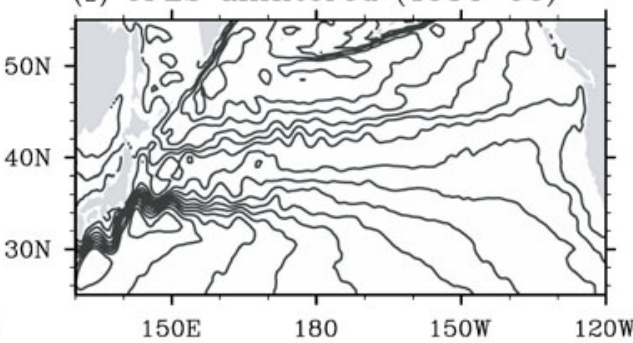

(d)

Rossby wave

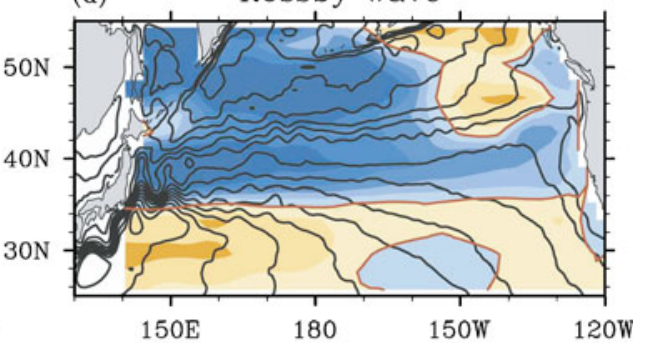

(e)

OFES frontal scale

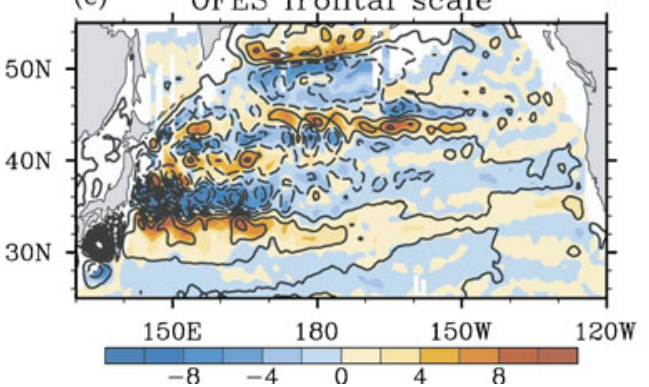

northern Okinawa Trough is rather unstable during the boreal winter-spring season.

One of the advantages in the high-resolution models like OFES is that circulations within the marginal seas and their interactions with the basin-scale circulations are well incorporated into the model. Qu et al. (2006) highlighted such an interaction between the South China Sea and the maritime continent and the Pacific Ocean. The OFES

results show that $0.1 \mathrm{~Sv}$ of freshwater and $0.2 \mathrm{PW}$ of heat are transported from the South China Sea into the maritime continent in average, suggesting a "heat capacitor" role of the South China Sea and a more active role in heat and freshwater budgets in the Indonesian Sea, western Pacific, and eastern Indian Oceans than previously thought.

Horizontal resolution of the wind fields that force the ocean models sometimes causes significantly different
Fig. 7 Dynamics of recirculation gyre in the Kuroshio extension region in the northwestern Pacific Ocean. Distribution of the Reynolds stress convergence on the $27.575 \sigma_{\Theta}$ surface, averaged for 5 years from 2000 to 2004 of the NCEP Run. White contours indicate the geostrophic stream functions on the same density surface. Contour interval is $2,000 \mathrm{~m}^{2} / \mathrm{s}$, and the dashed lines denote the negative values (from Qiu et al. 2008)

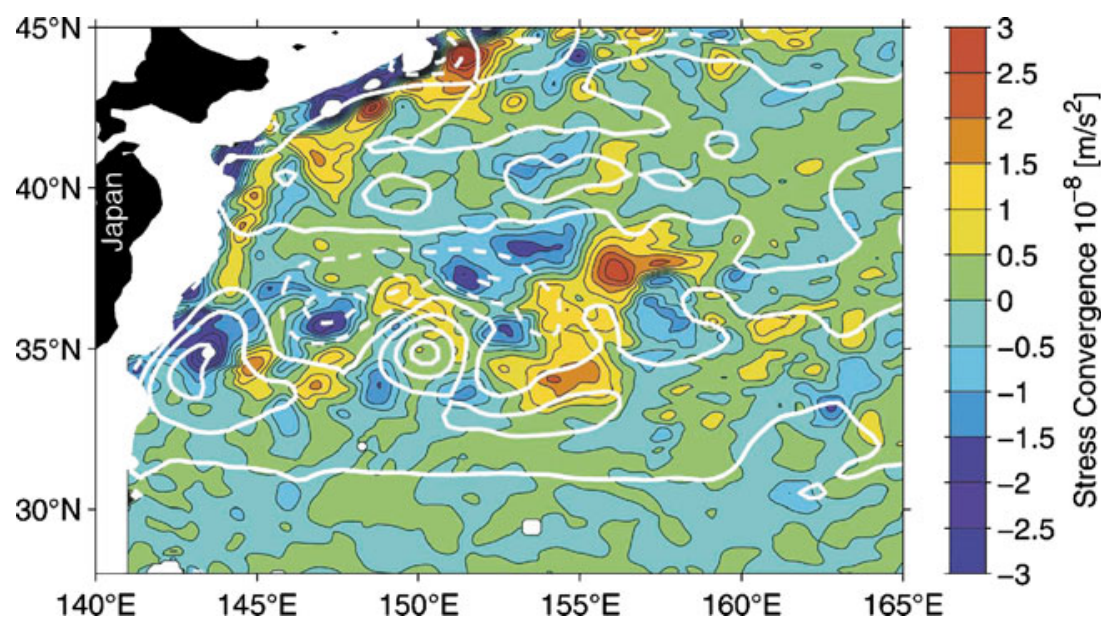


Fig. 8 Responses of surface currents to the winds near Hawaiian islands. Distribution of simulated current vectors at the depth of $38 \mathrm{~m}$ and surface wind stress curl (color shade) averaged over August/September/ October season from 2001 to 2004. Results in a QSCAT Run and b NCEP Run (from Sasaki and Nonaka 2006)

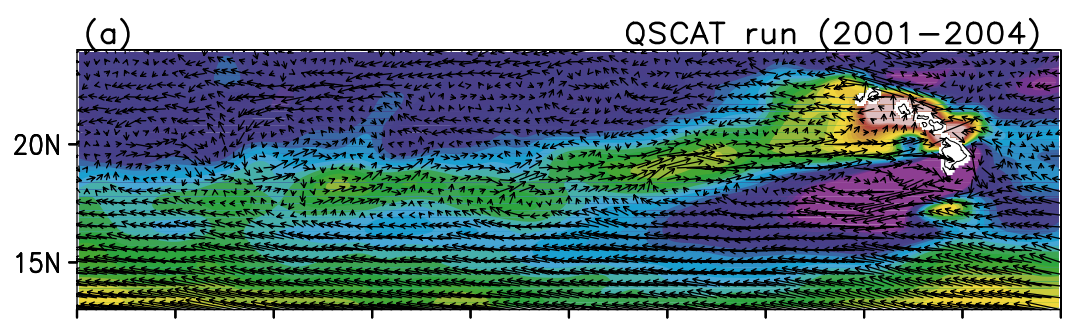

(b)

NCEP run (2001-2004)

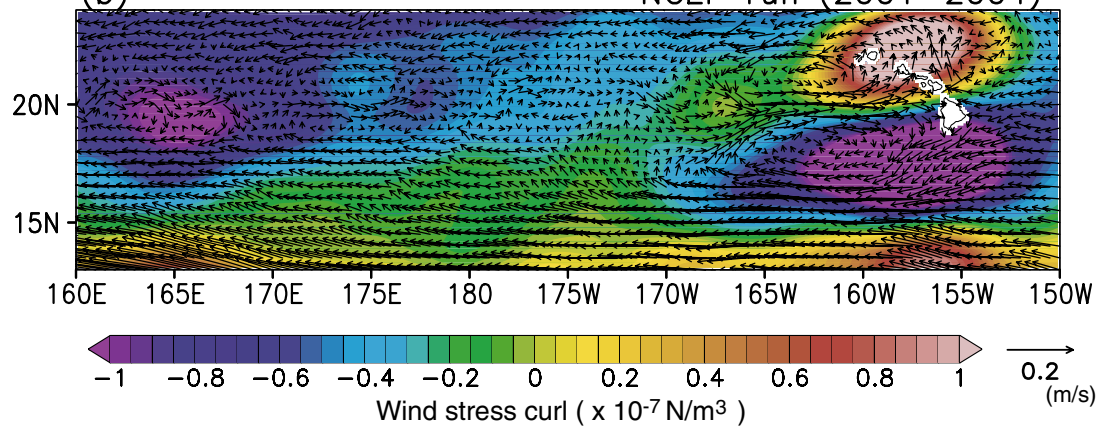

responses in the model results. An example of such influences can be seen in the Hawaiian Lee Countercurrent (HLCC) region between the dateline and the Hawaiian Islands (Sasaki and Nonaka 2006; Sasaki et al. 2010). The HLCC in the results forced by the QSCAT satellite wind field extends much further to the west-southwest from the Hawaiian Islands with a narrower structure than that in the results forced by the NCEP winds (Fig. 8). The HLCC varies seasonally with strong currents in boreal summer to winter and weak in spring, associated with the seasonal migration of the northeast trade winds. The westwardpropagating Rossby waves, excited by local dipole structure in the wind stress curl near Hawaii, contribute the most among possible processes to the seasonal variations of the HLCC (Sasaki et al. 2010). Significant interannual variations are also suggested from both the observations and the hindcast simulations.

Long-term variability in the sea surface height (SSH) and associated ocean variability in the South Pacific Ocean are investigated by Sasaki et al. (2008b). The EOF analysis of the SSH field shows a large-scale mono-pole structure as a leading mode with the maximum amplitude in the western and central South Pacific in the subtropical gyre region (Fig. 9). This mode exhibits decadal time-scale variability with high SSH during early- and mid-1970s and after the end of 1990s and low SSH period between them. The analyses indicate that the decadal variability in the $\mathrm{SSH}$ field is associated with changes in strength of the subtropical gyre and meso-scale eddy activities around the Tasman Front. Association with the decadal time-scale variability in El Niño/Southern Oscillation phenomena is also suggested.

Climate variations over the South Pacific Ocean generate temperature and salinity anomalies in the eastern subtrop-

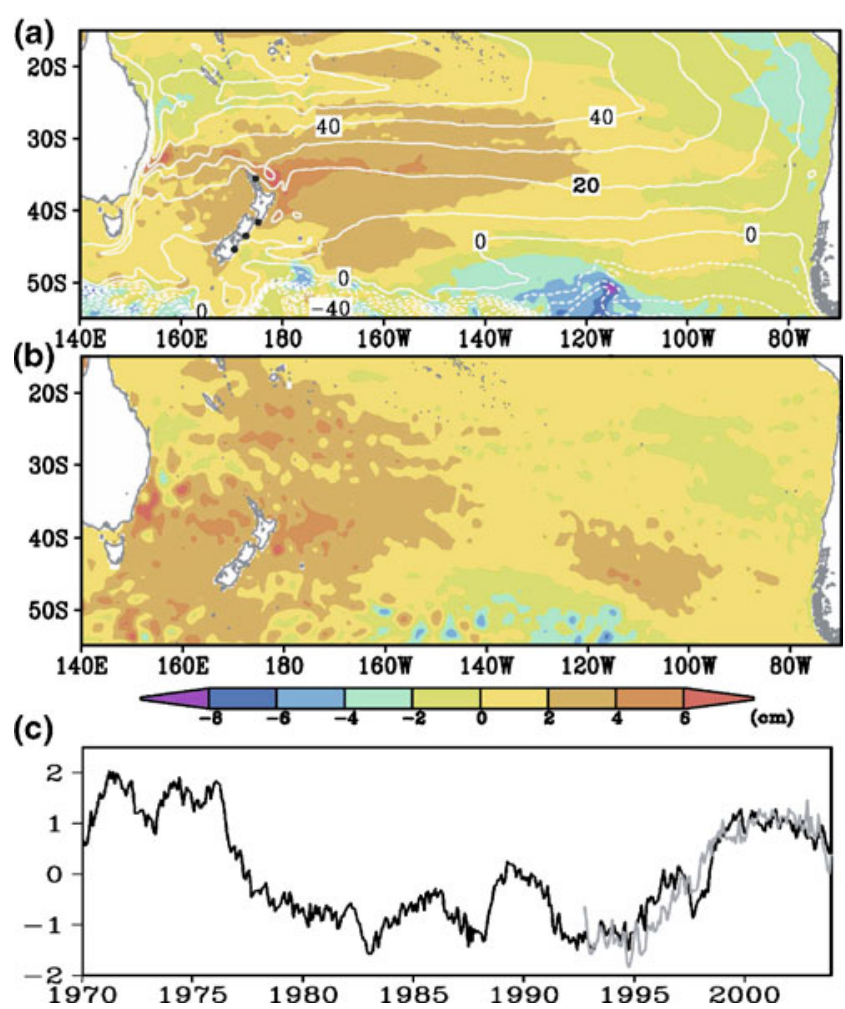

Fig. 9 Decadal variations in the SSH field in the South Pacific Ocean. a Spatial structure of the first EOF of the monthly SSH anomalies during a period from January 1970 to December 2003 in the NCEP Run. White contours denote the climatological SSH distribution, with the contour interval of $10 \mathrm{~cm}$. b Same as in a, but for combined satellite altimetry observations for the period from October 1992 to December 2003. c Normalized principal components of the first EOF in OFES simulation (black line) and that derived from satellite observation (gray line) (based on Sasaki et al. 2008b) 
ical region (Nonaka and Sasaki 2007). These anomalies, often called spiciness anomalies, propagate equatorward on an isopycnal surface, affecting even in the subsurface layer in the equatorial region with a time lag of about 5 years (Fig. 10). A mechanism responsible for the generation of these spiciness anomalies on $\sigma_{\theta}=25.3 \mathrm{~kg} \mathrm{~m}^{-3}$ is suggested to be associated with the density-compensating effect of temperature and salinity in this region, which generates weak meridional surface density gradient in climatological conditions. Cool temperature anomaly pushes the outcrop line of the isopycnal surface equatorward, hence the warm and salty anomalies on the isopycnal surface.

\subsection{Variability in the Indian Basin}

Descriptions of several phenomena in the Indian Ocean from the OFES results are highlighted in Masumoto et al. (2008), including the heat transport associated with the meridional overturning circulation and the Indonesian throughflow from the Pacific to Indian Oceans. For the meridional heat transport in the tropical Indian Ocean, Godfrey et al. (2007) and Hu and Godfrey (2007) show that the OFES results produce the closest values to the observed one among several OGCMs with various resolutions and configurations (Fig. 11). Since the simulated heat transport in the results forced by the daily QSCAT winds that include synoptic scale atmospheric variability is larger than the one forced by climatological winds, they suggest a possibility of rectification of shorter time-scale variability to the mean heat transport.

The equatorial and coastal waves and currents in the Indian Ocean are reproduced quite realistically in OFES, and this leads to detailed investigations on the mechanisms of several phenomena. A bifurcation of the coastal currents along the east coast of Sri Lanka is investigated in Vinayachandran et al. (2005). They show the relation between the bifurcation occurrence and intrusion of an anticyclonic eddy that propagates westward ahead of a
Fig. 10 Generation of temperature anomaly and subsequent propagation on an isopycnal surface in the southwestern Pacific Ocean. Longitude-time sections of temperature anomalies (in ${ }^{\circ} \mathrm{C}$ ) on $25.3 \sigma_{\Theta}$ surface averaged between a $2^{\circ} \mathrm{N}-2^{\circ} \mathrm{S}$ and $\mathbf{b} 13^{\circ} \mathrm{S}-17^{\circ} \mathrm{S}$ in NCEP Run. Note that the longitude axis is reversed and compressed in a. c Time series of outcrop latitude of $25.3 \sigma_{\Theta}$ surface averaged between $100^{\circ} \mathrm{W}$ and $120^{\circ} \mathrm{W}$ (black line) and $90^{\circ} \mathrm{W}$ and $100^{\circ} \mathrm{W}$ (green line). d Time series of area mean SSTA averaged over $15^{\circ} \mathrm{S}-25^{\circ} \mathrm{S}$, $100^{\circ} \mathrm{W}-120^{\circ} \mathrm{W}$ (black line), $15^{\circ} \mathrm{S}-25^{\circ} \mathrm{S}, 90^{\circ} \mathrm{W}-100^{\circ} \mathrm{W}$ (green line), and $4^{\circ} \mathrm{S}-4^{\circ} \mathrm{N}$, $90^{\circ} \mathrm{W}-150^{\circ} \mathrm{W}$ (red line). The equatorial SSTA variability is multiplied by 0.5 for easy comparison (from Nonaka and Sasaki 2007)

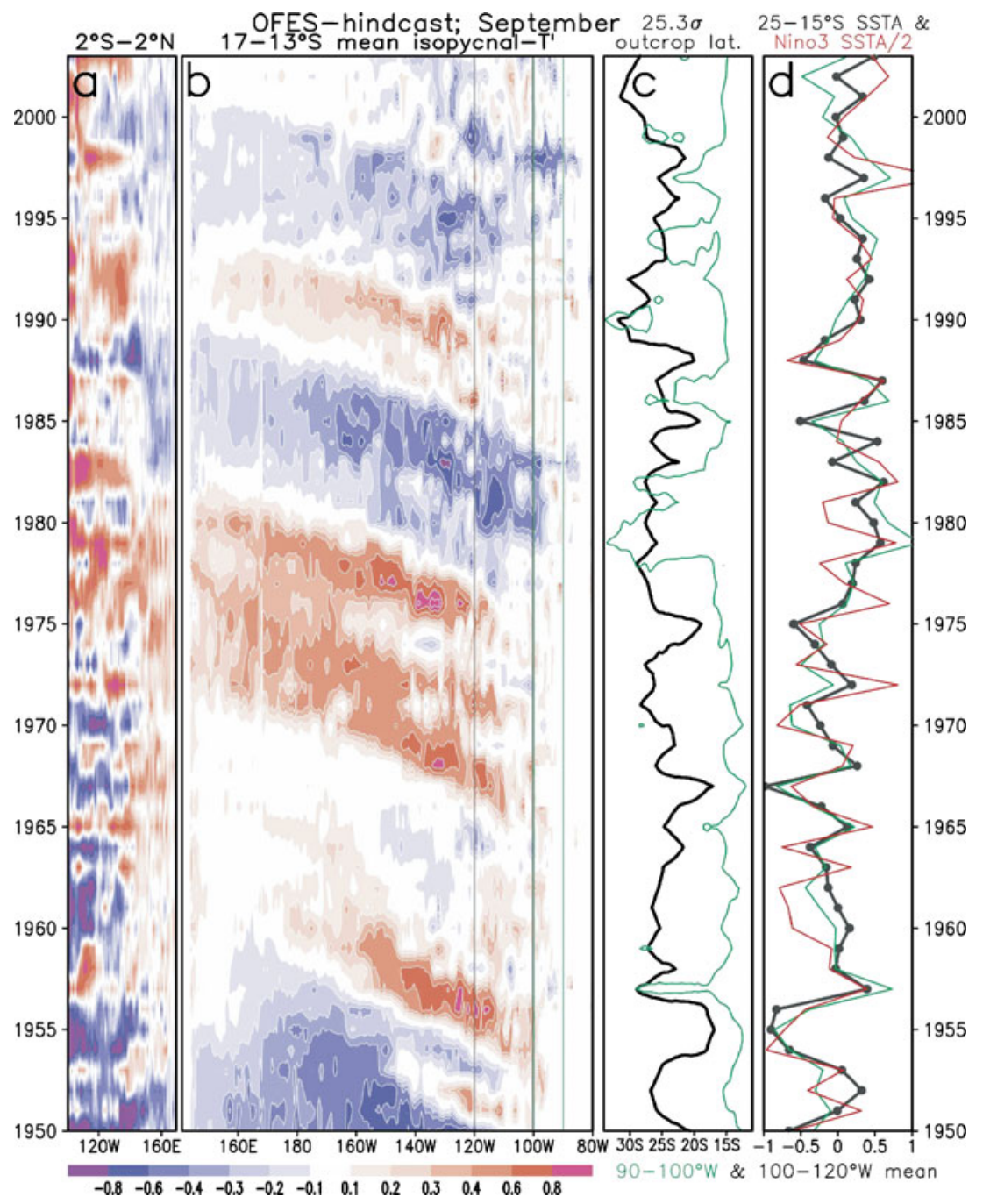




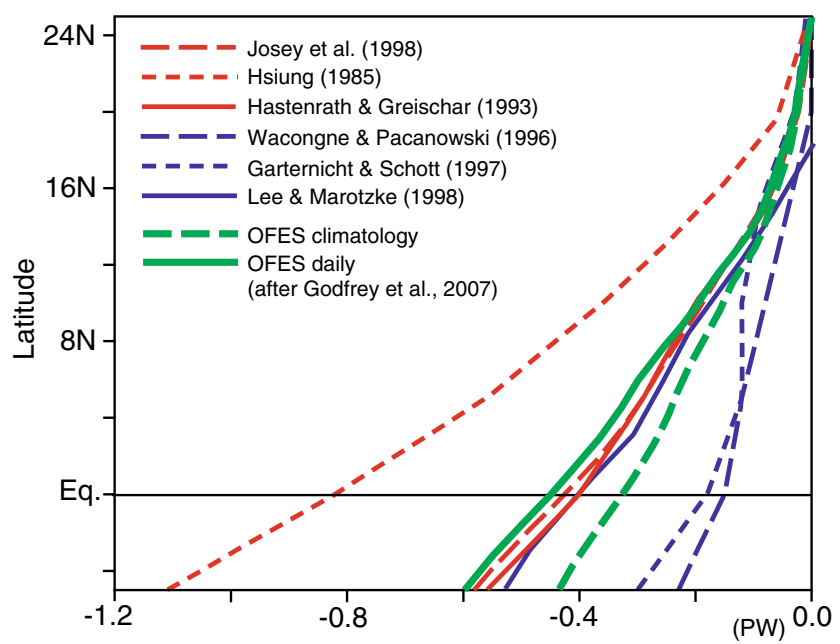

Fig. 11 Zonally integrated, annual mean meridional heat transport across each latitude north of $5^{\circ} \mathrm{S}$ within the Indian Ocean. Results from the OFES Climatology Run (green dashed line) and NCEP Run (green solid line) are shown, together with values calculated from the atmospheric flux data and those from other numerical model simulations (from Masumoto et al. 2008) downwelling Rossby wave front and suggest the importance of the bifurcation on transport of the low-salinity water from the Bay of Bengal to the equatorial region and the Arabian Sea.

Du et al. (2005) explore a seasonal heat budget in the southeastern tropical Indian Ocean, focusing on the coastal upwelling region along the eastern boundaries. The analyses indicate three different dynamical regimes within the region: the surface heat flux controls the seasonal variation of SST near the coast of northwest Australia, advection of the Indonesian throughflow balances with the cold upwelling along the south coast of Java and farther to the east, and a thick barrier layer hinders the cold thermocline water from entering the mixed layer west of Sumatra (Fig. 12).

The variations of the upper ocean along the eastern boundaries of the Indian Ocean are strongly affected by coastally trapped propagating signals, of which the intraseasonal component is studied by Iskandar et al. (2006). The analyses of the surface and subsurface currents along the Java coast indicate that the surface South Java Coastal
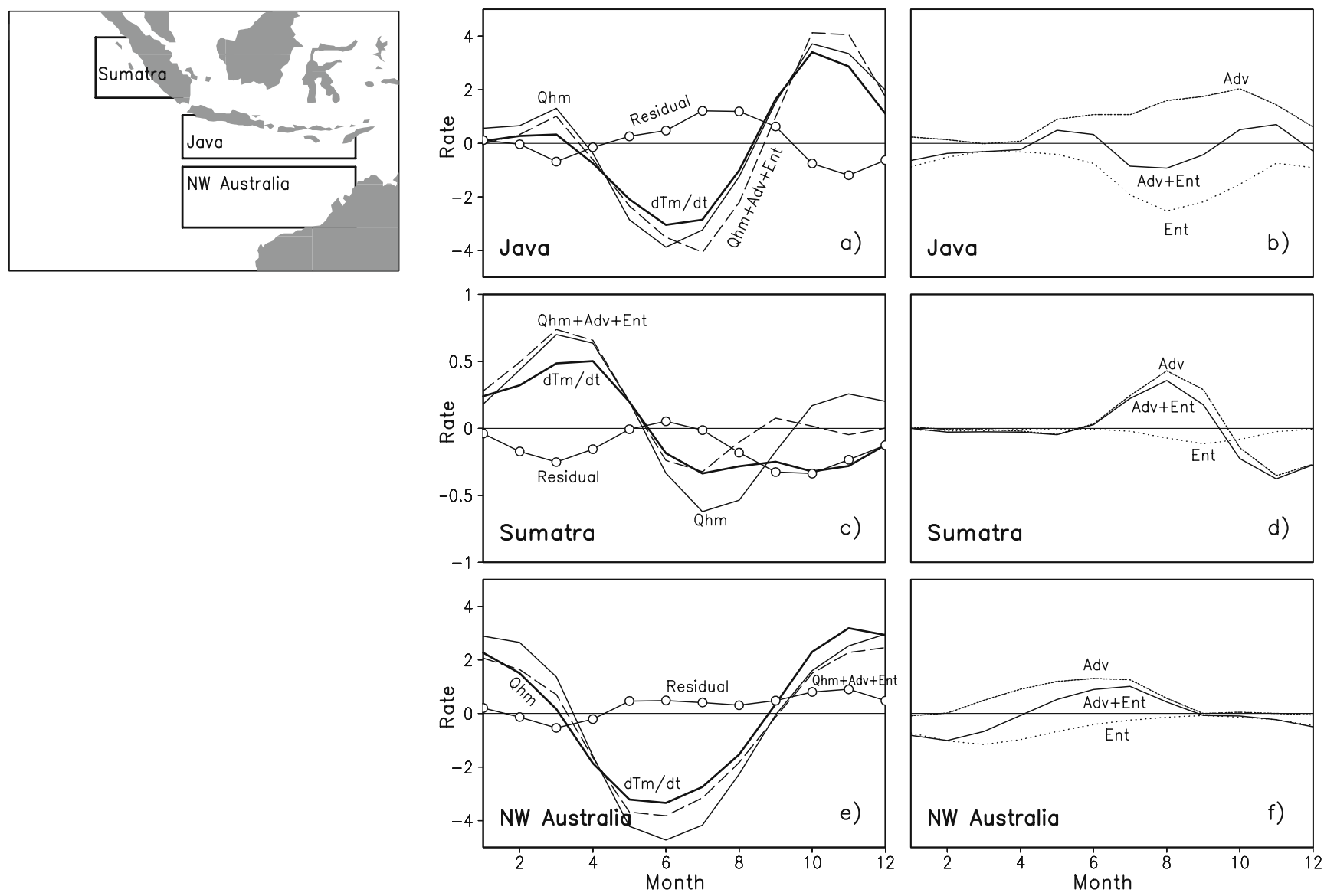

Fig. 12 Heat budget in the upper mixed-layer in the southeastern Indian Ocean. Time series of temperature tendency (bold lines), surface thermal forcing (thin solid lines), sum of surface thermal forcing, horizontal advection and vertical entrainment (bold dashed lines), and residual flux (solid lines with open circles) for regions off the coast of a Java, c Sumatra, and e Northwestern Australia. Time series of horizontal advection (bold lines), vertical entrainment (dotted lines), and sum of these two components (solid lines) are shown for the regions off $\mathbf{b}$ Java, $\mathbf{d}$ Sumatra, and $\mathbf{f}$ Northwestern Australia. Locations of three regions are indicated in a map at the top left (after Du et al. 2005) 
Current is dominated by variations with a period of 90 days, which is associated with the first baroclinic mode Kelvin waves generated in the central equatorial Indian Ocean. On the other hand, in the subsurface South Java Coastal Undercurrent, 60-day variations are the most prominent feature, which are captured by the second baroclinic mode and are excited by winds over the eastern equatorial Indian Ocean off Sumatra.

Ogata et al. (2008) investigate structures and propagating characteristics of the meridional current variability in the equatorial Indian Ocean. The analyses indicate that the variability at the time-scale of about 15 days is associated with the mixed Rossby-gravity waves forced mostly by meridional winds over the eastern equatorial Indian Ocean. It is also shown that a part of the wave energy penetrates into a deep ocean along the theoretical ray path of the mixed Rossby-gravity waves, generating the intraseasonal current variability even at the depth of $4,000 \mathrm{~m}$ at some particular locations (Fig. 13).

\subsection{Variability in the Atlantic Basin}

There are attempts to understand the meso-scale eddy effects on the circulation in the North Atlantic Ocean, using daily mean outputs of the OFES Climatology Run (Nakamura and Kagimoto 2006a, b). This pair of papers explores dynamical characteristics in terms of potential vorticity framework and transient wave activity concept. The analyses indicate that the eddies play an important role in the generation and maintenance of the mean potential vorticity fields and that substantial wave energy emanates from the Gulf Stream and the eastern North Atlantic in the thermocline and upper deep layers, respectively (Fig. 14). It is also shown that the eddies do not necessarily behave as "diffuser", which raises an issue of positively diffusive eddy mixing parameterization utilized in many models.

Studies on variations of thermal dome structures in the tropical Atlantic Ocean have been conducted (Doi et al. 2007, 2009). The Angola Dome and the Guinea Dome are the two thermal domes in the eastern Atlantic Ocean off the western coast of African. They affect significantly on local fisheries and possibly on the regional climate systems. Doi et al. $(2007,2009)$ investigate the mechanisms responsible for the seasonal and interannual variability of these domes and concluded that remote influences associated with the Atlantic Niño/Niña and the Atlantic Meridional Mode, as well as the local wind stress curl over the dome regions, play an essential role in their interannual variations (Fig. 15). They also indicate a possible link of the variability in the Angola Dome and strength of the subsurface eastward currents in the equatorial region (Doi et al. 2007).

\subsection{Variability in the Antarctic Region}

Characteristics of meso-scale eddies in the Antarctic Divergence zone off Adélie coast are described from the OFES results, together with the data from satellite and in
Fig. 13 Biweekly meridional current and wind variability along the equator in the Indian Ocean. a Zonal distribution of the standard deviation of the biweekly meridional wind stress variability along the equator and b longitude-depth section of the standard deviation of the meridional current variability along the equator at the biweekly period, during the period from March to May 2002 simulated in OFES NCEP Run. The standard deviation of the current variability is normalized by the zonally averaged value at each depth, and the vertical distribution of the zonally averaged standard deviation is indicated in c. Black dots in b show a ray path of the biweekly mixed Rossby-gravity wave (From Ogata et al. 2008)

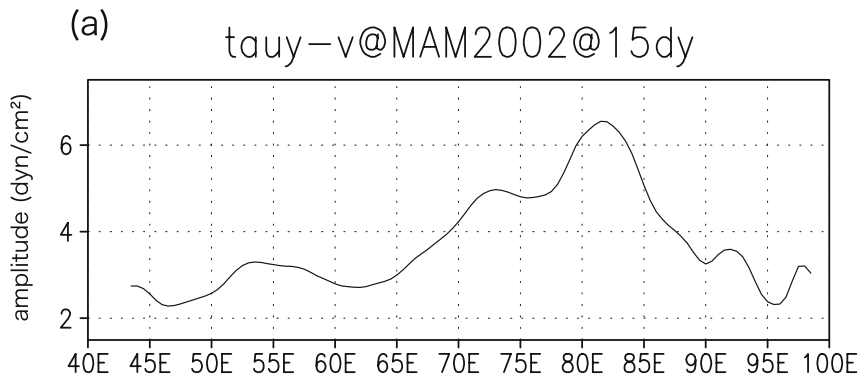

(b)

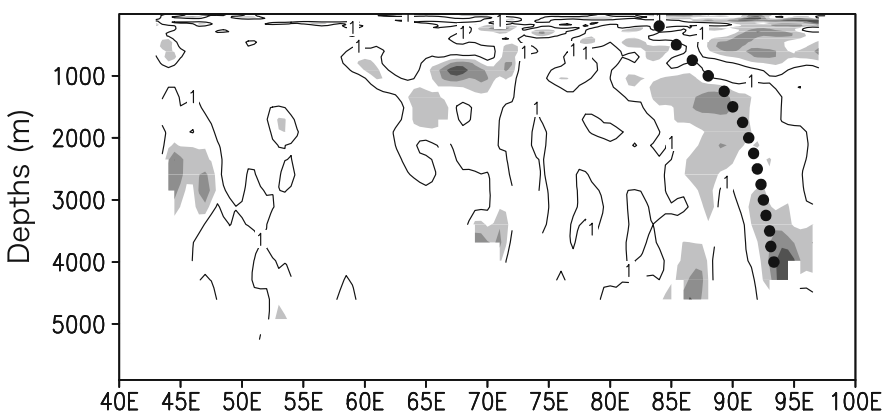

(c)

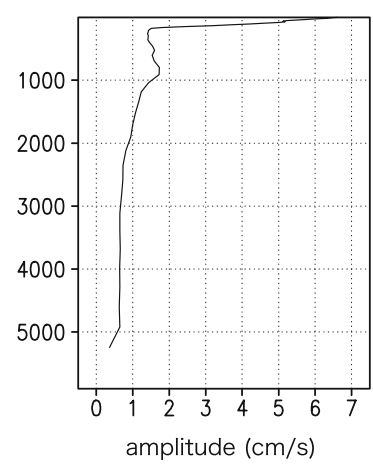


(a)

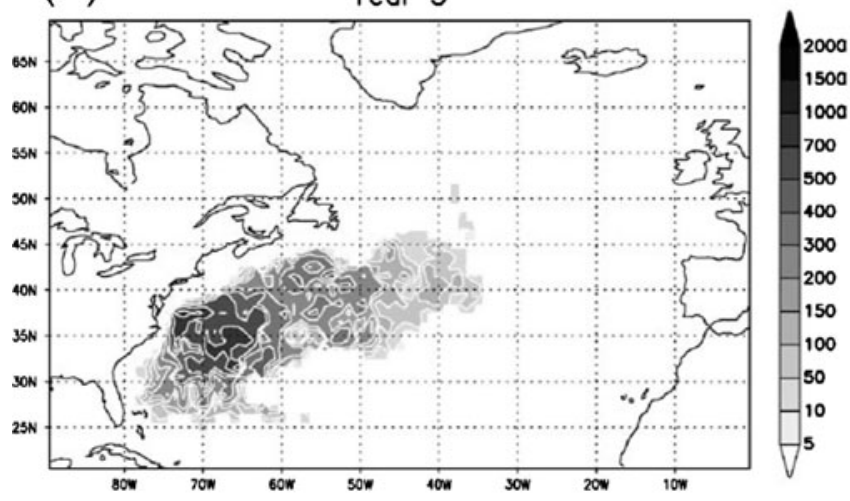

(b)

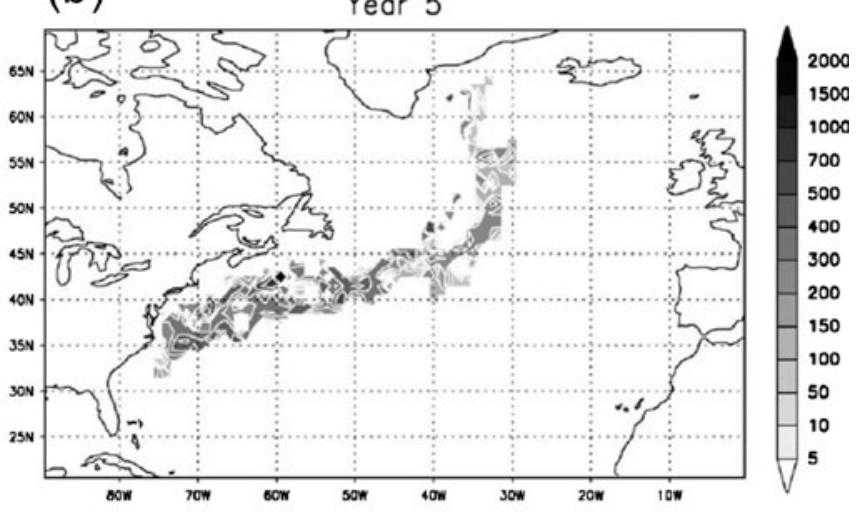

(c) Northward Total M Flux $\left(\mathrm{m}^{2} \mathrm{~s}^{-2}\right)$ \& Mean Flow $(\mathrm{m} / \mathrm{s})$ at $60^{\circ} \mathrm{W}$

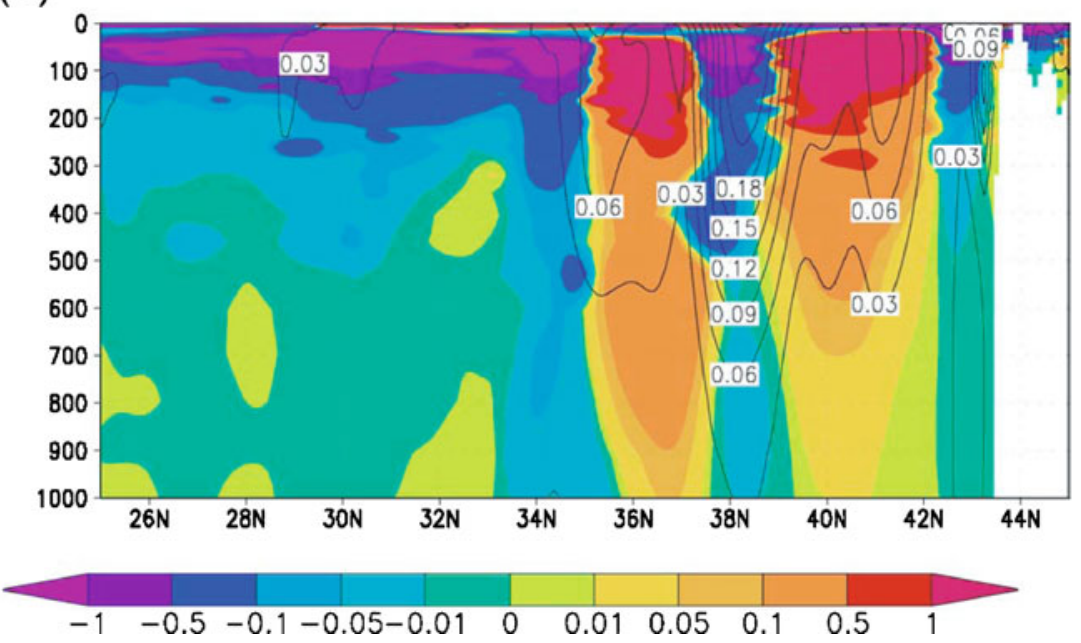

Fig. 14 Effects of eddy variability on the circulation in the northwestern Atlantic Ocean. The time-integrated particle density on the $\sigma_{\theta}=27.1$ surface derived from trajectory calculations using the results of OFES Climatology Run at the end of the fifth year for a a case with variable currents associated with the eddy activities and $\mathbf{b}$ a case only with the mean flow. The units are particles per box of $1^{\circ} \times$ $1^{\circ}$. The particles are released in a $2^{\circ} \times 2^{\circ}$ box centered at $74^{\circ} \mathrm{W}$ and

situ observations (Aoki et al. 2007a). A series of cyclonic meso-scale eddies, whose cores are occupied by cold and fresh anomalies, is observed (Fig. 16). The OFES results well simulate these eddies with significant barotropic structure and suggest that the eddies are originated further west over the continental slope region and play an important role in the mixing processes across the Antarctic Divergence zone.

Aoki et al. (2007b) explore the characteristics of the mixed-layer thickness in the subantarctic mode water formation regions in the Southern Ocean. The analysis indicates that regions of deep mixed-layer thickness appear between the Subantarctic Front to their south and mixedlayer thickness front to their north in the eastern part of Indian and Pacific sectors (Fig. 17). It is confirmed that the mixed-layer thickness front is located along a line of zero $35^{\circ} \mathrm{E}$. The influence of the eddies can be seen as the particles spread in a wider and shorter area along the Gulf Stream path (after Nakamura and Kagimoto 2006a). c Latitude-depth section of the meridional wave activity flux (color shade) and zonal mean current (contours) at $60^{\circ} \mathrm{W}$. Divergences in the wave activity flux can be seen at the location of the Gulf Stream at $38^{\circ} \mathrm{N}$ and the secondary core of the mean zonal flow at $35^{\circ} \mathrm{N}$ (after Nakamura and Kagimoto 2006b)

surface temperature and density advections associated with the surface geostrophic flow. Influence of bottom topography on the location of the maximum in the mixed-layer depth is also suggested.

\section{Analyses of biogeochemical/ecosystem aspects using OFES results}

One of the important aspects of the OFES project is collaboration between physical and biogeochemical/ecosystem researchers. This is achieved by the use of a CFC tracer equation and a simple NPZD-type ecosystem model embedded in the OFES. Since biogeochemical tracers can be considered as good indicators of ocean circulations not only in the deep oceans but also in the coastal and other 
(a) $\mathrm{HCA}$ in Box A

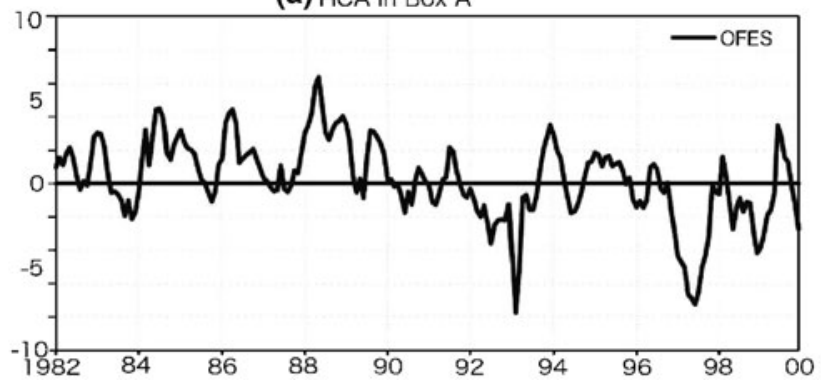

(c) SSTA in ATL3

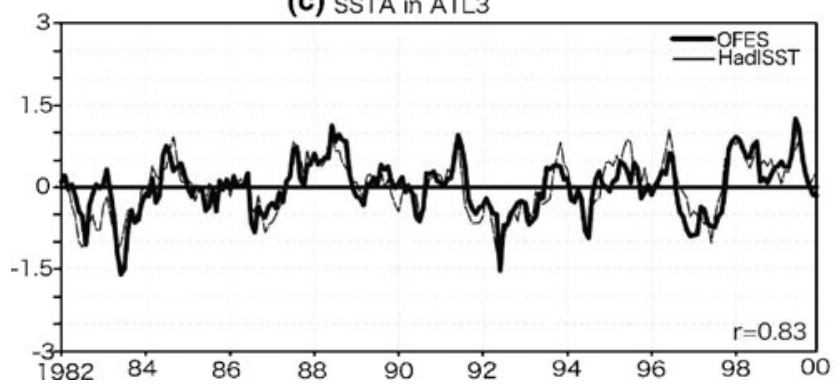

(b) SSHA in Box A

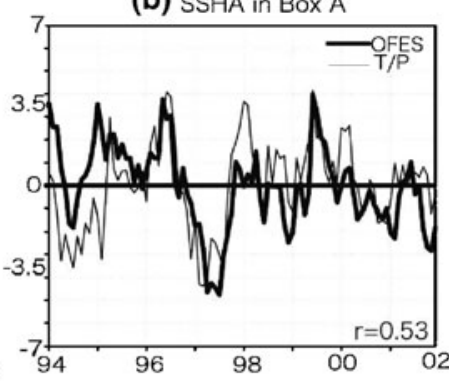

(d) SSHA in ATL3

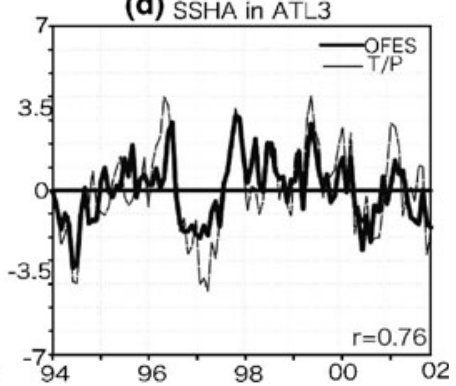

Fig. 15 Relation between upper ocean heat content variability in the Angola Dome and equatorial Atlantic regions. Time series of a the heat content anomaly in the upper 58-m depth from 1982 to 2000 and b the sea surface height anomaly from 1994 to 2002 for the OFES NCEP Run (thick line) and the TOPEX/Poseidon altimetry data (thin line), both at the location of the Angola Dome (box A; $7.5^{\circ} \mathrm{S}-4.5^{\circ} \mathrm{S}$, $0.5^{\circ} \mathrm{W}-2.5^{\circ} \mathrm{E}$ ). Time series of $\mathbf{c}$ the sea surface temperature anomaly from 1982 to 2000 for the OFES (thick line) and HadISST data (thin line) and d the SSHA from 1994 to 2002 for the OFES (thick line) and the TOPEX/Poseidon (thin line), both in the ATL3 region $\left(3^{\circ} \mathrm{S}-3^{\circ} \mathrm{N}\right.$, $\left.20^{\circ} \mathrm{W}-0^{\circ} \mathrm{E}\right)$. The correlation coefficients between the OFES results and observation data are shown in each panel. The correlation between the HCA in the Angola Dome and the SSTA in the ATL3 indicates that the maximum value of 0.49 with the SSTA leads the HCA by 1 month. The correlation between the SSHAs in two regions also show the similar value and phase relation, suggesting the relation between the Atlantic Niño and the interannual variations of the Angola Dome (from Doi et al. 2007)
Fig. 16 Structure of cyclonic eddy in the Antarctic Divergence off Adelie Coast. a Latitude-depth section of the eastward velocity along $140^{\circ} \mathrm{E}$ on January 25, 2006 from the OFES NCEP Run. Vertical profiles of $\mathbf{b}$ the potential temperature and salinity along the $140^{\circ}$ E on January 25, 2006. Contour intervals for temperature and salinity are $0.5^{\circ} \mathrm{C}$ and $0.1 \mathrm{psu}$, respectively. Note that axes in $\mathbf{a}$ are different from $\mathbf{b}$ and $\mathbf{c}$. Center of the cyclonic eddy is denoted by a black triangle on the top of each panel (after Aoki et al. 2007a) (a)

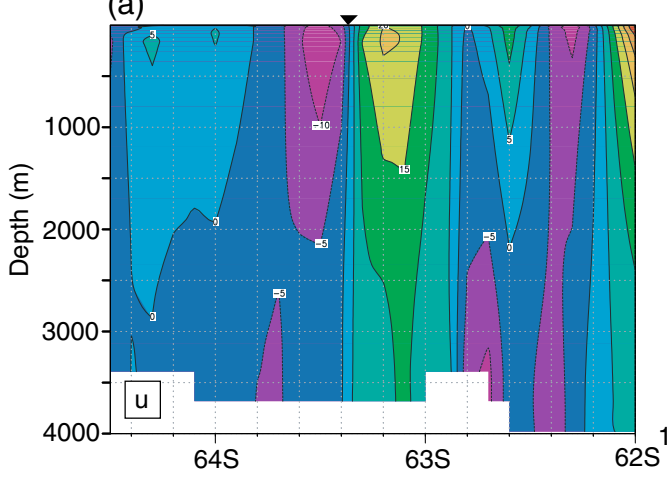

(c)

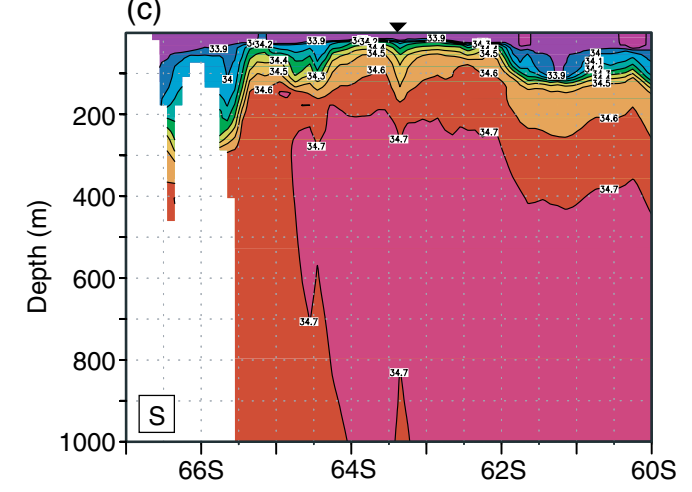

(b)

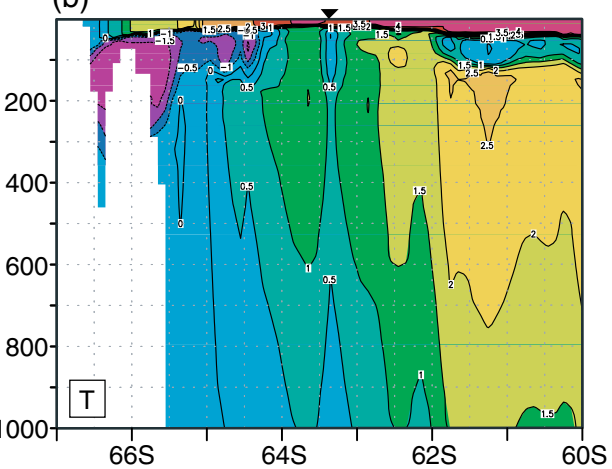

605 


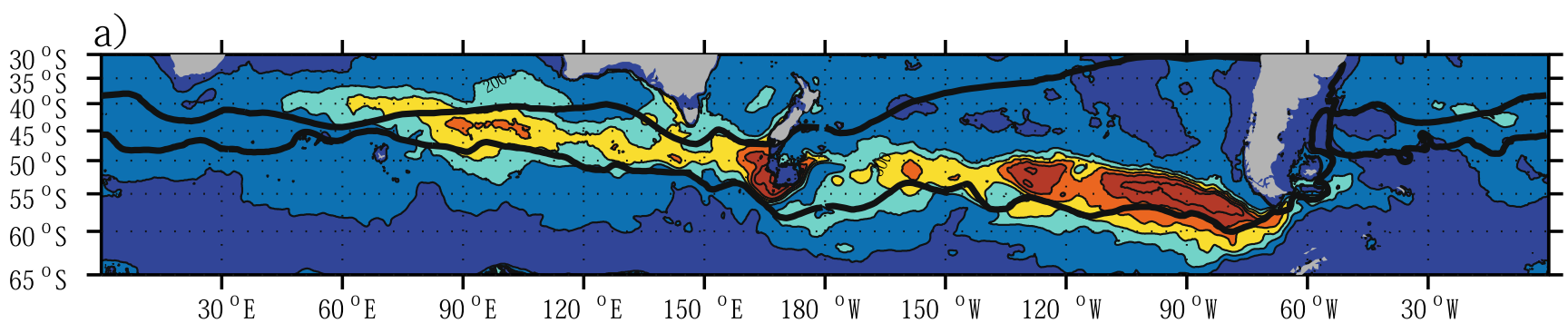

b)

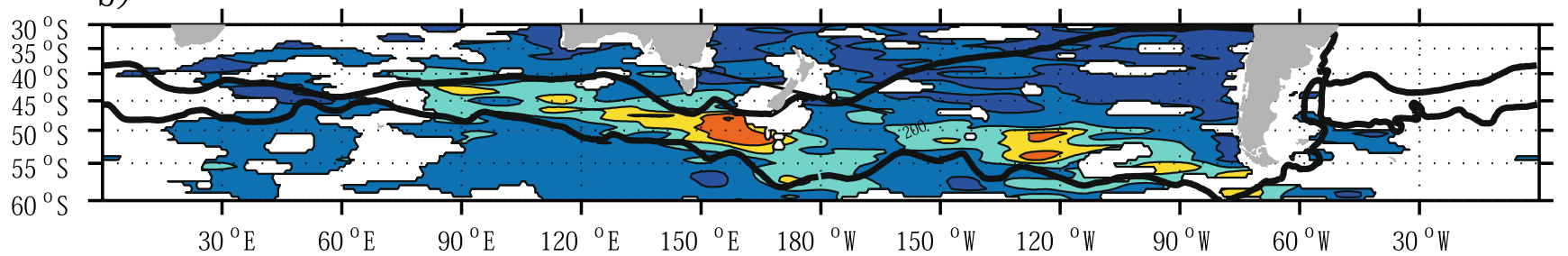

Fig. 17 Deep mixed-layer depth in formation regions of subantarctic mode water in the southern ocean. Distribution of mixed-layer depth, derived from a OFES and b Argo floats. Thick black lines indicate the subtropical front and subantarctic front (from Aoki et al. 2007b)

Fig. 18 Simulated CFC-11 distribution in the Weddell Sea. a A plan view of the annual mean CFC-11 distribution at the depth of 2,000 $\mathrm{m}$ in 1990. Annual mean horizontal velocity is also plotted with white arrows (from Sasai et al. 2004). b A three-dimensional view of the monthly mean CFC-11 field in October 1990. A high concentration of CFC-11 in Antarctic bottom water appears along the western boundary region of the Weddell Sea, flowing to the Scotia Sea over the South Scotia Ridge. A part of the AABW flows eastward along the South Scotia Ridge and enters Antarctic Circumpolar Current (from Sasai et al. 2005) (a)

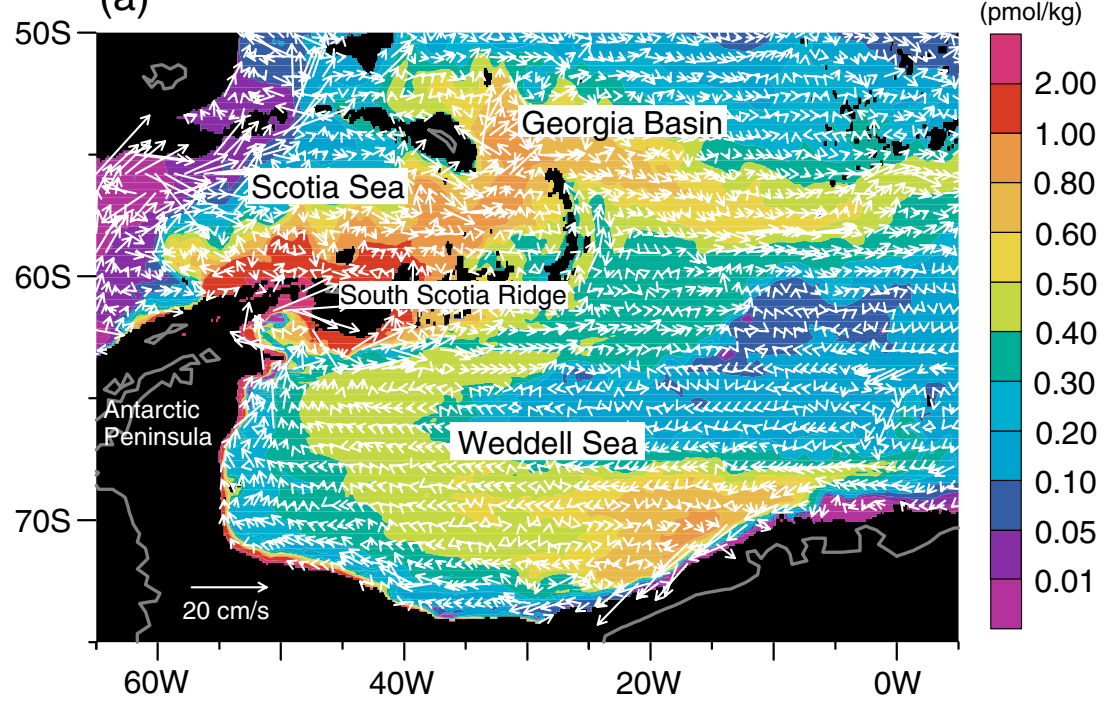

(b)

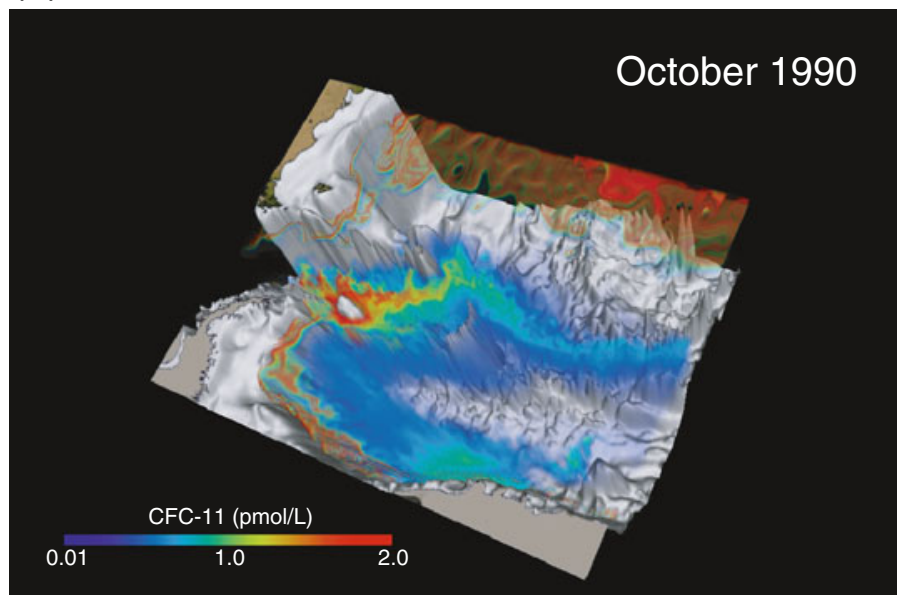


upper oceans, it is natural to develop cooperation between the physics-oriented and biogeochemical/ecosystem-oriented studies. Current activities in this direction mainly separate into two groups. One group analyzes the tracers in the model simulated on-line with physical parameters. Another group focuses more on ecosystem aspects and the OFES results are utilized for off-line Lagrangian particle tracking calculations. Examples of such studies in the two groups are briefly summarized in this section.

5.1 On-line simulation of CFC distribution and ecosystem dynamics

The Antarctic Bottom Water (AABW) pathway is explored using the distribution of CFC-11 in OFES by Sasai et al. (2004) and Sasai et al. (2005). OFES demonstrate a significant skill in reproducing CFC-11 distribution at the sections along $0^{\circ} \mathrm{E}$ (AJAX) and $170^{\circ} \mathrm{W}$ (WOCE P15S) and in generating pathways of the $\mathrm{AABW}$. The simulated CFC-11 distribution indicates two pathways from the Weddell Sea to the AJAX section: an upper route through the Scotia Sea and a deeper route along the South Scotia Ridge (Fig. 18). The model suggests that the AABW is generated in the Weddell Sea, offshore region of Wilkes Land, and in the Ross Sea. It turns out that the AABW formed in the Weddell Sea spreads to the east in the Antarctic Circumpolar Current and then flows to the north into the Argentine Basin, while the AABW from Wilkes Land joins with the component from the Ross Sea.

Overall performance in simulating biological fields in the North Pacific Ocean in the physical-biological coupled integration is described in Sasai et al. (2006, 2007b). Comparison between the OFES results and the satellite ocean color observations shows that the model is capable of realistic description of the annual mean field, its seasonal and intraseasonal variability, and regional patterns of the surface chlorophyll concentration, in which both the Kuroshio and meso-scale eddies play important roles. It also turns out that the small-scale features, such as the meso-scale eddies, frontal structures, and local upwelling, have significant impacts on the upper-ocean nitrate distribution.

Seasonal variations of marine biology in the eastern tropical Pacific Ocean is investigated as a first attempt to check performances of biological simulations in OFES, with particular focus on surface chlorophyll concentration (Sasai et al. 2007a). The model reproduced realistic seasonal variations of the nutrient and chlorophyll concentration associated with the development of the Costa Rica Dome in boreal summer and with generation of meso-scale eddies forced by strong winds through three isthmuses in Central America during winter season (Fig. 19). In both seasons, upwelling due to wind stress curl plays an essential role in the evolution of the biological processes.

\subsection{Lagrangian particle tracking analyses}

The particle tracking calculations are utilized so far to estimate movements of eggs and larvae of the Japanese anchovy and sardine (Itoh et al. 2009) and the Japanese eel (Kim et al. 2007; Zenimoto et al. 2009) and for understanding the migration of Pacific bluefin tuna (Kitagawa et al. 2009). It is interesting to know that the surrounding
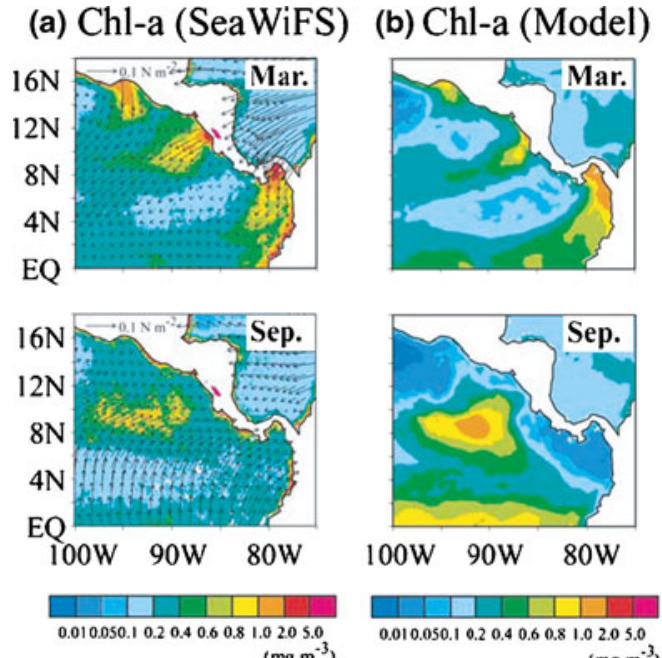

( $\mathrm{mg} \mathrm{m}^{-3}$ )
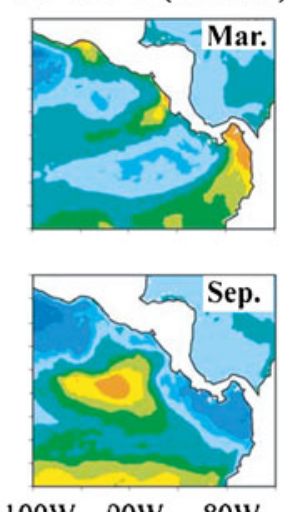

100W $90 \mathrm{~W} 80 \mathrm{~W}$

0.010 .050 .10 .20 .40 .60 .81 .02 .05 .0 (c) SST \& Vel.
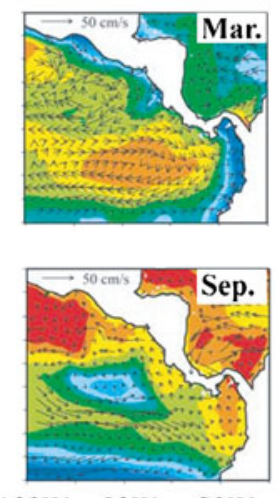

100W 90W $80 \mathrm{~W}$

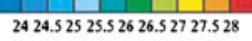

( $\left.{ }^{\circ} \mathrm{C}\right)$ (d) Nitr. \& TD
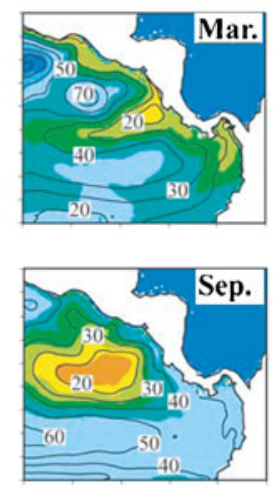

100W $90 \mathrm{~W} 80 \mathrm{~W}$

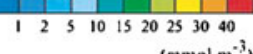

$\left(\mathrm{mmol} \mathrm{m}{ }^{-3}\right)$
Fig. 19 Horizontal distributions of monthly climatological mean surface chlorophyll concentration $\left(\mathrm{mgm}^{-3}\right)$ of a SeaWiFS observation with QSCAT wind stress (vectors in $\mathrm{N} \mathrm{m}^{-2}$ ) in the eastern tropical Pacific Ocean and b simulated results in OFES Climatology Run. c Simulated sea surface temperature $\left({ }^{\circ} \mathrm{C}\right)$ and horizontal velocity at $25-\mathrm{m}$ depth (vectors in $\mathrm{cm} \mathrm{s}^{-1}$ ). $\mathbf{d}$ Mean nitrate concentration $\left(\mathrm{mmol} \mathrm{Nm}^{-3}\right)$ in the upper $75-\mathrm{m}$ depth and thermocline depth (contours in meter, $20^{\circ} \mathrm{C}$ isotherm depth) are also plotted. The simulated chlorophyll concentration (in $\mathrm{mg} \mathrm{chl} \mathrm{m}^{-3}$ ) is computed from nitrogen using a constant ratio of 1.59 g chlorophyll per mol nitrogen (from Sasai et al. 2007a) 
Fig. 20 Particle trajectories released at the spawning ground of the Japanese eel in the western tropical Pacific Ocean. a Four cases in which the particles were released from a fixed spawning ground at $14^{\circ} \mathrm{N}$, $142^{\circ} \mathrm{E}$ (denoted with open circles). b Same as in a, but meridional migration of spawning latitude $(S L)$ associated with the location of the salinity front at $142^{\circ} \mathrm{E}$ is considered for each year (from Zenimoto et al. 2009)

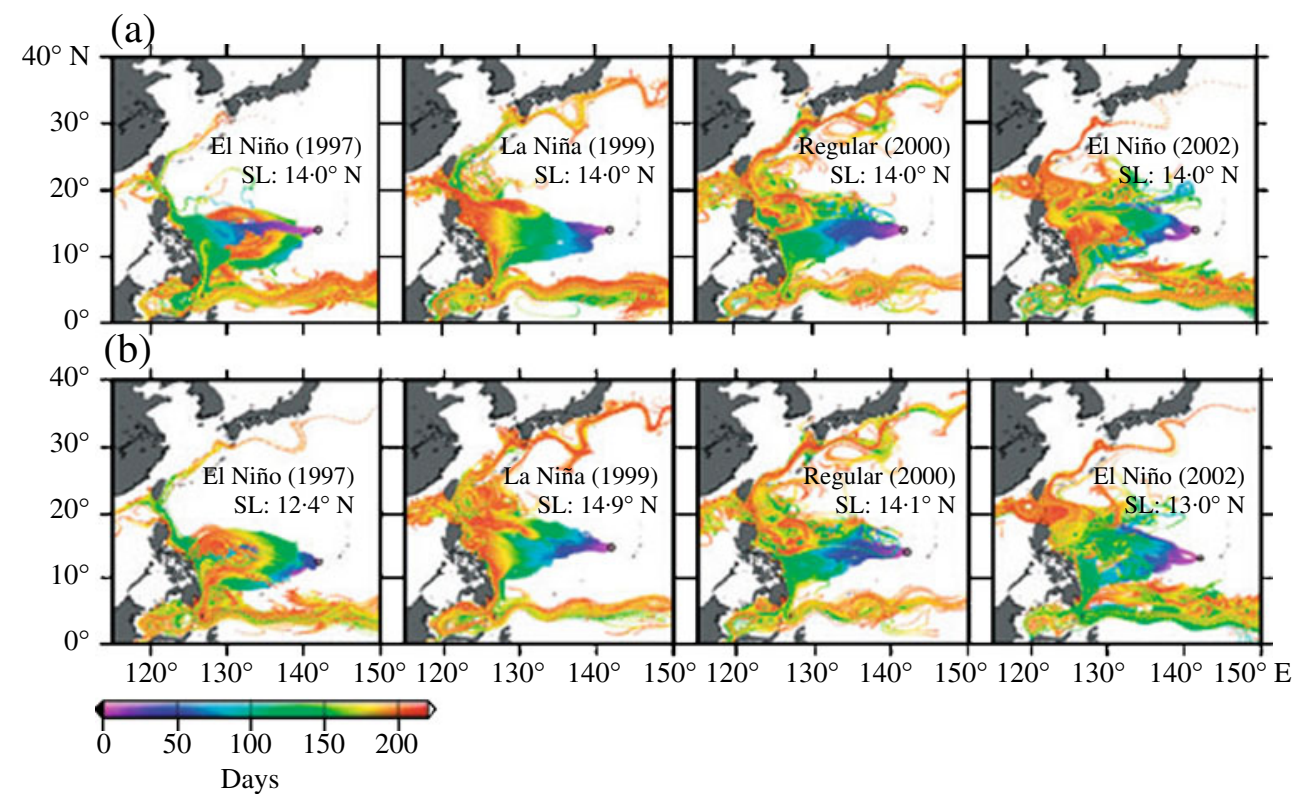

temperature during the egg period for both the Japanese anchovy and sardine determines the subsequent recruitment rate and amount of fish. The eggs and larvae of both the anchovy and sardine flow along the southern coast of Japan by the strong Kuroshio currents and are transported to the KOCER, but modeled anchovy tends to be trapped more in coastal regions compared to the sardine case (Itoh et al. 2009).

The Japanese eel is believed to spawn in the western equatorial Pacific and its larvae are transported to the coastal areas of Japan along the Kuroshio flow. Kim et al. (2007) and Zenimoto et al. (2009) investigate the influences of ENSO phenomena on the eel migrations. Analyses indicates that the transport of eel larvae to the Kuroshio reduces during the El Niño years compared to the non-El Niño years, due to changes in location of the salinity front and the North Equatorial Current bifurcation latitude (Fig. 20). They also suggest the importance of meso-scale eddies on the distribution of the eel larvae in the northwestern Pacific Ocean.

From analyses of locations of the tagged bluefin tunas during their trans-Pacific migration and the OFES temperature fields, Kitagawa et al. (2009) suggest that the bluefin tuna tends to migrate along the Subarctic Frontal Zone, staying much of the time in a region of colder water just north of the front (Fig. 21).

\section{Future activities}

Although contributions of the OFES results to the abovementioned studies vary widely depending on the contents and the way of analyses, all the studies demonstrate significant utilities of the OFES outputs and their value in quantitative analyses on many processes in the oceans. This

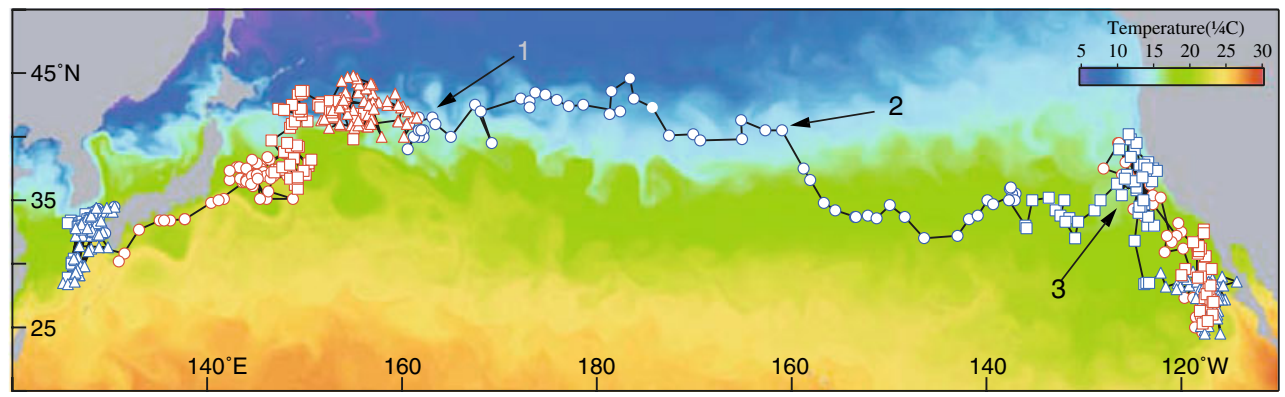

Fig. 21 Migration pathway of the archival-tagged Pacific bluefin tuna in the north Pacific Ocean between Japan and North America, with sea surface temperature data for November 1997 (blue open circle, November-December; blue open square, January-February; blue open triangle, March-April; red open circle, May-June; red open square, July-August; red open triangle, September-October). Arrow 1 indicates the day when the fish initiated trans-Pacific migration (11 November 1997), arrow 2 the day when the fish changed its direction of movement to the southeast (8 December 1997), and arrow 3 the day when the fish arrived in the eastern Pacific (15 January 1998) (from Kitagawa et al. 2009) 
encouraging situation makes us continue and further improve the high-resolution modeling activity under the OFES project. Our hindcast integrations with the NCEP/ NCAR reanalysis product and the QSCAT wind data (NCEP Run and QSCAT Run in Fig. 2) will be extended to the end of 2009 in the near future. Further integrations beyond 2010 are also being planned.

There are of course several issues that were recognized during our analyses of the OFES results when they are compared with the observed fields. Those include shallower mixed-layer depth in a wide area of the North Pacific Ocean, cool bias in the sea surface temperature in the Indian Ocean, different behavior of Kuroshio path variations south of Japan, and inadequate representation of the water mass properties within the Indonesian archipelago. Some of the issues seem to be related to insufficient parameterizations of the sub-grid scale phenomena and some are associated with the surface boundary conditions. We are now testing and are planning to check performances of different parameterizations of the mixed layer physics and lateral/vertical mixing processes, which might be implemented in future versions of OFES. The surface forcing should also be improved for better representation of the sea surface temperature and the other variables in the surface and subsurface layers, since there are notable differences in the results forced by NCEP reanalysis data and those forced by QuikScat winds.

The relatively strong restoring term toward the seasonal climatology for the surface salinity tends to reduce the intraseasonal, interannual, and longer time-scale variations in the simulated salinity field. Development of barrier layer and, hence, mixed-layer processes in some regions could also be affected by this restoring term. With high-resolution precipitation data, such as products derived from satellite observations, and river run-off data for the major rivers, the boundary condition for the surface fresh water flux would be improved and will be implemented in a future model.

One of the large issues for the present OFES model is the lack of sea ice component, which is important for higher-latitude ocean conditions and their variability as well as water mass formation in many places of the world ocean. A new version of the OFES model with the sea ice processes embedded, called Coupled Ocean-Sea Ice Model for the Earth Simulator (OIFES), has been developed and tested extensively (Komori et al. 2005). OIFES has been used as an oceanic component of Coupled GCM for the Earth Simulator (Komori et al. 2008) and is utilized for a new basin-scale, much higher resolution model, with $1 / 30^{\circ}$ horizontal grid spacing and 100 vertical levels. The latter model focuses on studies about the subtropical and subarctic gyres in the North Pacific, interactions between the Pacific Ocean and its marginal seas including the Sea of Okhotsk and the Arctic Ocean. The 1/30 ${ }^{\circ}$ resolution North
Pacific model is now being integrated and tested on a new Earth Simulator, which was upgraded on March 2009.

The OFES outputs that are not available for download at this moment and the ones from the future works will also be available for the community, under cooperative research bases at the beginning and, hopefully, freely afterwards. We, the OFES group, are expecting that the existing and planned datasets stimulate many scientists in the physical, chemical, and biological fields and are used extensively to contribute toward a better understanding of the oceanic conditions and variations.

Acknowledgment OFES model integrations were conducted on the Earth Simulator maintained by the Earth Simulator Center. The original idea of the OFES project was suggested by Prof. Yamagata and the late Dr. Miyoshi, who was the leader of the development team of the Earth Simulator. Constructive comments from two anonymous reviewers improved the manuscript a lot.

Open Access This article is distributed under the terms of the Creative Commons Attribution Noncommercial License which permits any noncommercial use, distribution, and reproduction in any medium, provided the original author(s) and source are credited.

\section{References}

Antonov JI, Levitus S, Boyer TP, Conkright ME, O'Brien T, Stephens C (1998a) World ocean atlas 1998, vol 1: temperature of the Atlantic Ocean, NOAA atlas NES-DIS 27. US Government Printing Office, Washington, DC

Antonov JI, Levitus S, Boyer TP, Conkright ME, O'Brien T, Stephens C (1998b) World ocean atlas 1998, vol 2: temperature of the Pacific Ocean, NOAA atlas NESDIS 28. US Government Printing Office, Washington, DC

Antonov JI, Levitus S, Boyer TP, Conkright ME, O'Brien T, Stephens C, Trotsenko B (1998c) World ocean atlas 1998, vol 3: temperature of the Indian Ocean, NOAA atlas NESDIS 29. US Government Printing Office, Washington, DC

Aoki S, Fukai D, Hirawake T, Ushio S, Rintoul SR, Hasumoto H, Ishimaru T, Sasaki H, Kagimoto T, Sasai Y, Mitsudera H (2007a) A series of cyclonic eddies in the Antarctic Divergence off Adelie Coast. J Geophys Res 112:C05019. doi:10.1029/2006JC003712

Aoki S, Hariyama M, Mitsudera H, Sasaki H, Sasai Y (2007b) Formation regions of subantarctic mode water detected by OFES and Argo profiling floats. Geophys Res Lett 34:L10606. doi:10.1029/2007GL029828

Aoki K, Kubokawa A, Sasaki H, Sasai Y (2009) Midlatitude baroclinic Rossby waves in a high-resolution OGCM simulation. J Phys Oceanogr 39:2264-2279. doi:10.1175/2009JPO4137.1

Boyer TP, Levitus S, Antonov JI, Conkright ME, O’Brien T, Stephens C (1998a) World ocean atlas 1998, vol 4: salinity of the Atlantic Ocean, NOAA atlas NESDIS 30. US Government Printing Office, Washington, DC

Boyer TP, Levitus S, Antonov JI, Conkright ME, O'Brien T, Stephens C (1998b) World ocean atlas 1998, vol 5: salinity of the Pacific Ocean, NOAA atlas NESDIS 31. US Government Printing Office, Washington, DC

Boyer TP, Levitus S, Antonov JI, Conkright ME, O'Brien T, Stephens C, Trotsenko B (1998c) World ocean atlas 1998, vol 6: salinity of the Indian Ocean, NOAA atlas NESDIS 32. US Government Printing Office, Washington, DC 
Ceballos LI, Di Lorenzo E, Hoyos CD, Schneider N, Taguchi B (2009) North Pacific Gyre Oscillation synchronizes climate fluctuations in the Eastern and Western boundary systems. J Climate 22:5163-5174

Chassignet EP, Garraffo ZD (2001) Viscosity parameterization and the Gulf Stream separation. In: Muller P, Henderson D (eds) Aha Huliko'a Hawaiian winter workshop. University of Hawaii, pp 37-41

Chelton DB, Schlax G (1996) Global observation of oceanic Rossby waves. Science 272:234-238

Coward AC, de Cuevas BA, Webb DJ (2002) Early results from a $1 / 12^{\circ} \times$ $1 / 12^{\circ}$ global ocean model. Poster from WOCE Final Conference, http://www.soc.soton.ac.uk/JRD/OCCAM/POSTERS

Doi T, Tozuka T, Sasaki H, Masumoto Y, Yamagata T (2007) Seasonal and interannual variations of oceanic conditions in the Angola Dome. J Phys Oceanogr 37:2698-2713. doi:10.1175/2007JPO3552.1

Doi T, Tozuka T, Yamagata T (2009) Interannual variability of the Guinea Dome and its possible link with the Atlantic meridional mode. Clim Dyn 33:985-998. doi:10.1007/s00382-009-0574-z

Du Y, Qu T, Meyers G, Masumoto Y, Sasaki H (2005) Seasonal heat budget in the mixed layer of the southern tropical Indian Ocean in a high resolution ocean general circulation model. J Geophys Res 110:C04012. doi:10.1029/2004JC002845

Dutay J-C, Bullister JL, Doney SC, Orr JC, Najjar R et al (2002) Evaluation of ocean model ventilation with CFC11: comparison of 13 global ocean models. Ocean Model 4:89-120

Godfrey JS, Hu R-J, Schiller A, Fiedler R (2007) Explorations of the annual mean heat budget of the tropical Indian Ocean. Part I: studies with an idealized model. J Clim 20:3210-3228

$\mathrm{Hu}$ R-J, Godfrey JS (2007) Explorations of the annual mean heat budget of the tropical Indian Ocean. Part II: studies with a simplified ocean general circulation model. J Clim 20:3229-3248

Hurlburt HE, Hogan PJ (2000) Impact of $1 / 8^{\circ}$ to $1 / 64^{\circ}$ resolution on Gulf Stream model - data comparisons in basin-scale subtropical Atlantic Ocean models. Dyn Atmos Oceans 32:283-329

Iskandar I, Tozuka T, Sasaki H, Masumoto Y, Yamagara T (2006) Intraseasonal variations of surface and subsurface currents off Java as simulated in a high-resolution ocean general circulation model. J Geophys Res 111:C12015. doi:10.1029/2006JC003486

Itoh S, Yasuda I, Nishikawa H, Sasaki H, Sasai Y (2009) Transport and environmental temperature variability of eggs and larvae of the Japanese anchovy (Engraulis japonicus) and Japanese sardine (Sardinops melanostictus) in the western North Pacific estimated via numerical particle-tracking experiments. Fish Oceanogr $18: 118-133$

Kalnay E, Kanamitsu M, Kistler R, Collins W, Deaven D, Gandin L, Iredell M, Saha S, White G, Woollen J, Zhu Y, Chelliah M, Ebisuzaki W, Higgins W, Janowiak J, Mo KC, Ropelewski C, Leetmaa A, Reynolds R, Jenne R (1996) The NCEP/NCAR 40year reanalysis project. Bull Amer Meteor Soc 77:437-471

Kawai Y, Doi T, Tomita H, Sasaki H (2008) Decadal-scale changes in meridional heat transport across $24^{\circ} \mathrm{N}$ in the Pacific Ocean. J Geophys Res 113:C08021. doi:10.1029/2007JC004525

Killworth PD, Chelton DB, de Szoeke RA (1997) The speed of observed and theoretical long extratropical planetary waves. J Phys Oceanogr 27:1946-1966

Kim H, Kimura S, Shinoda A, Kitagawa T, Sasai Y, Sasaki H (2007) Effect of El Niño on migration and larval transport of the Japanese eel (Anguilla japonica). ICES J Mar Sci 64:1387-1395

Kitagawa T, Kimura S, Nakata H, Yamada H, Nitta A, Sasai Y, Sasaki H (2009) Immature Pacific bluefin tuna, Thunnus orientalis, utilizes cold waters in the Subarctic Frontal Zone for trans-Pacific migration. Environ Biol Fish 84:193-196. doi:10.1007/s10641008-9409-8

Komori N, Takahashi K, Komine K, Motoi T, Zhang X, Sagawa G (2005) Description of sea-ice component of coupled ocean-seaice model for the Earth Simulator (OIFES). J Earth Sim 4:31-45
Komori N, Kuwano-Yoshida A, Enomoto T, Sasaki H, Ohfuchi W (2008) High-resolution simulation of global coupled atmosphere-ocean system: description and preliminary outcomes of CFES (CGCM for the Earth Simulator). In: Hamilton K, Ohfuchi W (eds) High resolution numerical modelling of the atmosphere and ocean, chapter 14. Springer, New York, pp 241-260

Kubota M, Iwasaka N, Kizu S, Konda M, Kutsuwada K (2002) Japanese ocean flux data sets with use of remote sensing observations (J-OFURO). J Oceanogr 58:213-225

Kutsuwada K (1998) Impact of wind/wind-stress field in the north Pacific constructed by ADEOS/NSCAT data. J Oceanogr 54:443-456

Large WG, McWilliams JC, Doney SC (1994) Oceanic vertical mixing - a review and a model with a nonlocal boundary layer parameterization. Rev Geophys 32:363-403

Maltrud ME, McClean JL (2005) An eddy resolving global $1 / 10^{\circ}$ ocean simulation. Ocean Model 8:31-54

Masumoto Y, Sasaki H, Kagimoto T, Komori N, Ishida A, Sasai Y, Miyama T, Motoi T, Mitsudera H, Takahashi K, Sakuma H, Yamagata T (2004) A fifty-year eddy-resolving simulation of the world ocean-preliminary outcomes of OFES (OGCM for the Earth Simulator). J Earth Simulator 1:35-56

Masumoto Y, Morioka Y, Sasaki H (2008) High-resolution Indian Ocean simulations - recent advances and issues from OFES. In: Ocean modeling in an eddying regime. Geophysical Monograph Series 177, American Geophysical Union, pp 199-212, doi:10.1029/177GM14

Maximenko NA, Bang B, Sasaki H (2005) Observational evidence of alternating zonal jets in the world ocean. Geophys Res Lett 32: L12607. doi:10.1029/2005GL022728

Maximenko NA, Melnichenko OV, Niiler PP, Sasaki H (2008) Stationary mesoscale jet-like features in the ocean. Geophys Res Lett 35:L08603. doi:10.1029/2008GL033267

Melnichenko OV, Maximenko NA, Schneider N, Sasaki H (2010) Quasi-stationary striations in basin-scale oceanic circulation: vorticity balance from observations and eddy-resolving model. Ocean Dyn. doi:10.1007/s10236-009-0260-z

Merryfield WJ, Scott RB (2007) Bathymetric influence on mean currents in two high-resolution near-global ocean models. Ocean Model 16:76-94. doi:10.1016/j.ocemod.2006.07.005

Nakamura M, Kagimoto T (2006a) Potential vorticity and eddy potential enstrophy in the North Atlantic Ocean simulated by a global eddy-resolving model. Dyn Atm Oceans 41:28-59

Nakamura M, Kagimoto T (2006b) Transient wave activity and its fluxes in the North Atlantic Ocean simulated by a global eddyresolving model. Dyn Atm Oceans 41:60-84

Nakamura H, Nishina A, Ichikawa H, Nonaka M, Sasaki H (2008) Deep countercurrent beneath the Kuroshio in the Okinawa Trough. J Geophys Res 113:C06030. doi:10.1029/2007JC004574

Nonaka M, Sasaki H (2007) Formation mechanism for isopycnal temperature-salinity anomalies propagating from the Eastern South Pacific to the Equatorial Region. J Climate 20:13051315. doi:10.1175/JCLI4065.1

Nonaka M, Nakamura H, Tanimoto Y, Kagimoto T, Sasaki H (2006) Decadal variability in the Kuroshio-Oyashio extension simulated in an eddy-resolving OGCM. J Climate 19:1970-1989

Nonaka M, Nakamura H, Tanimoto Y, Kagimoto T, Sasaki H (2008) Interannual-to-decadal variability in the Oyashio and its influence on temperature in the Subarctic Frontal Zone: an eddy-resolving OGCM simulation. J Climate 21:6283-6303. doi:10.1175/2008JCLI2294.1

Ogata T, Sasaki H, Murty VSN, Sarma MSS, Masumoto Y (2008) Intraseasonal meridional current variability in the eastern equatorial Indian Ocean. J Geophys Res 113:C07037. doi:10.1029/ 2007JC004331

Ohfuchi W, Sasaki H, Masumoto Y, Nakamura H (2005) Mesoscale resolving simulations of the global atmosphere and ocean on the Earth Simulator. Eos 86(5):45 
Ohfuchi W, Sasaki H, Masumoto Y, Nakamura H (2007) "Virtual" atmospheric and oceanic circulation in the Earth Simulator. Bull Amer Meteor Soc 88(6):861-866

Oschlies A (2001) Model-derived estimates of new production: new results point towards lower values. Deep-Sea Res 48:2173-2197

Pacanowski RC, Gnanadesikan A (1998) Transient response in a $z$ level ocean model that resolves topography with partial cells. Mon Weather Rev 126:3248-3270

Pacanowski RC, Griffies SM (2000) MOM 3.0 manual. Geophysical Fluid Dynamics Laboratory/National Oceanic and Atmospheric Administration, $680 \mathrm{pp}$

Qiu B, Chen S, Hacker P, Hogg NG, Jayne SR, Sasaki H (2008) The Kuroshio extension northern recirculation gyre: profiling float measurements and forcing mechanism. J Phys Oceanogr 38:1764-1779. doi:10.1175/2008JPO3921.1

Qu T, Chen J (2009) A North Pacific decadal variability in subduction rate. Geophys Res Lett 36:L22602. doi:10.1029/2009GL040914

Qu T, Du Y, Sasaki H (2006) South China Sea throughflow: a heat and freshwater conveyor. Geophys Res Lett 33:L23617. doi:10.1029/ 2006GL028350

Rhines PB (1975) Waves and turbulence on a beta-plane. J Fluid Mech 69:417-443

Richards KJ, Maximenko NA, Bryan FO, Sasaki H (2006) Zonal jets in the Pacific Ocean. Geophys Res Lett 33:L03605. doi:10.1029/ 2005GL024645

Richards K, Sasaki H, Bryan F (2008) Jets and waves in the Pacific Ocean. In: Hamilton K, Ohfuchi W (eds) High resolution numerical modelling of the atmosphere and ocean, chapter 11. Springer, New York, pp 187-196

Rosati A, Miyakoda K (1988) A general circulation model for upper ocean circulation. J Phys Oceanogr 18:1601-1626

Sasai Y, Ishida A, Yamanaka Y, Sasaki H (2004) Chlorofluorocarbons in a global ocean eddy-resolving OGCM: pathway and formation of Antarctic Bottom Water. Geophys Res Lett 31:L12305. doi:10.1029/2004GL019895

Sasai Y, Ishida A, Sasaki H, Kawahara S, Uehara H, Yamanaka Y (2005) Spreading of Antarctic Bottom Water examined using the CFC-11 distribution simulated by an eddy-resolving OGCM. Polar Meteorol Glaciol 19:15-27

Sasai Y, Ishida A, Sasaki H, Kawahara S, Uehara H, Yamanaka Y (2006) A global eddy-resolving coupled physical-biological model: physical influences on a marine ecosystem in the North Pacific. Simulation 82(7):467-474, 19

Sasai Y, Sasaki H, Sasaoka K, Ishida A, Yamanaka Y (2007a) Marine ecosystem simulation in the eastern tropical Pacific with a global eddy resolving coupled physical-biological model. Geophys Res Lett 34:L23601. doi:10.1029/2007GL031507

Sasai Y, Sasaoka K, Sasaki H, Ishida A (2007b) Seasonal and intraseasonal variability of chlorophyll-a in the North Pacific: model and satellite data. J Earth Sim 8:3-11

Sasaki H, Nonaka M (2006) Far-reaching Hawaiian Lee Countercurrent driven by wind-stress curl induced by warm SST band along the current. Geophys Res Lett 33:L13602. doi:10.1029/ 2006GL026540

Sasaki H, Sasai Y, Nonaka M, Masumoto Y, Kawahara S (2006) An eddy-resolving simulation of the quasi-global ocean driven by satellite-observed wind field - preliminary outcomes from physical and biological fields. J Earth Sim 6:35-49

Sasaki H, Taguchi B, Nonaka M, Masumoto Y (2007) A series of quasi-global eddy-resolving ocean simulations. CLIVAR Exchanges 12(3):5-7

Sasaki H, Nonaka M, Masumoto Y, Sasai Y, Uehara H, Sakuma H (2008a) An eddy-resolving hindcast simulation of the quasiglobal ocean from 1950 to 2003 on the Earth Simulator. In: Hamilton K, Ohfuchi W (eds) High resolution numerical modelling of the atmosphere and ocean, chapter 10. Springer, New York, pp $157-$ 185

Sasaki YN, Minobe S, Schneider N, Kagimoto T, Nonaka M, Sasaki H (2008b) Decadal sea level variability in the South Pacific in a global eddy-resolving ocean model hindcast. J Phys Oceanogr 38:1731-1747. doi:10.1175/2007JPO3915.1

Sasaki H, Xie S-P, Taguchi B, Nonaka M, Masumoto Y (2010) Seasonal variations of the Hawaiian Lee Countercurrent induced by the meridional migration of the trade winds. Ocean Dyn. doi:10.1007/s10236-009-0258-6

Semtner AJ, Chervin RM (1992) Ocean general circulation from a global eddy-resolving model. J Geophys Res 97:5493-5550

Smith RD, Maltrud ME, Bryan FO, Hecht MW (2000) Numerical simulation of the North Atlantic Ocean at 1/10. J Phys Oceanogr 30:1532-1561

Taguchi B, Xie S-P, Schneider N, Nonaka M, Sasaki H, Sasai Y (2007) Decadal variability of the Kuroshio extension: observations and an eddy-resolving model hindcast. J Climate 20:23572377. doi:10.1175/JCLI4142.1

Tailleux R, McWilliams JC (2001) The effect of bottom pressure decoupling on the speed of extratropical, baroclinic Rossby waves. J Phys Oceanogr 31:1461-1476

Vinayachandran PN, Kagimoto T, Masumoto Y, Chauhan P, Nayak SR, Yamagata T (2005) Bifurcation of the East India coastal current east of Sri Lanka. Geophys Res Lett 32:L15606. doi:10.1029/2005GL022864

Von Storch J-S, Sasaki H, Marotzke J (2007) Wind-generated power input to the deep ocean: an estimate using a $1 / 10^{\circ}$ general circulation model. J Phys Oceanogr 37:657-672. doi:10.1175/ JPO3001.1

Walker SJ, Weiss RF, Salameh PK (2000) Reconstructed histories of the annual mean atmospheric mole fractions for halocarbons CFC-11, CFC-12, CFC-113, and carbon tetrachloride. J Geophys Res 105:14285-14296

Zenimoto K, Kitagawa T, Miyazaki S, Sasai Y, Sasaki H, Kimura S (2009) The effects of seasonal and interannual variability of oceanic structure in the Western Pacific North Equatorial Current on larval transport of the Japanese eel Anguilla japonica. J Fish Biol 74:1878-1890. doi:10.1111/j.1095-8649.2009.02295.x 